\begin{tabular}{|c|l|}
\hline Title & $\begin{array}{l}\text { Distribution and sources of organic matter in surficial sediments on the shelf and slope off Tokachi, western North } \\
\text { Pacific, inferred from C and N stable isotopes and C /N ratios }\end{array}$ \\
\hline Author(s) & $\begin{array}{l}\text { Usui, Toshihiro; Nagao, Seiya; Y amamoto, Masanobu; Suzuki, Koji; Kudo, Isao; Montani, Shigeru; Noda, A tsushi; } \\
\text { Minagawa, Masao }\end{array}$ \\
\hline Citation & $\begin{array}{l}\text { Marine Chemistry, 98(2-4), 241-259 } \\
\text { https://doi.org/10.1016j.marchem.2005.10.002 }\end{array}$ \\
\hline Issue Date & 2006-02 \\
\hline Doc URL & http://hdl.handle.net/2115/4871 \\
\hline Type & article (author version) \\
\hline File Information & MC98(2-4).pdf \\
\hline
\end{tabular}

Instructions for use 
Submitted to Marine Chemistry

\section{Distribution and sources of organic matter in surficial sediments on the shelf and slope off Tokachi, western North Pacific, inferred from C and $\mathrm{N}$ stable isotopes and $\mathrm{C} / \mathrm{N}$ ratios}

Toshihiro Usui $^{*}$, Seiya Nagao ${ }^{1}$, Masanobu Yamamoto ${ }^{1}$, Koji Suzuki ${ }^{1}$ Isao Kudo², Shigeru Montani ${ }^{3}$, Atsushi Noda ${ }^{4}$ and Masao Minagawa ${ }^{1}$

${ }^{1}$ Research Faculty of Environmental Earth Science, Hokkaido University, N10, W5, Sapporo 060-0810, Japan

${ }^{2}$ Research Faculty of Fisheries Sciences, Hokkaido University,

N13, W8, Sapporo, 060-0813, Japan

${ }^{3}$ Graduate School of Environmental Science, Hokkaido University,

N13, W8, Sapporo, 060-0813, Japan

${ }^{4}$ Institute of Geoscience and Geoinformation, National Institute of Advanced Industrial Science and Technology, Tsukuba 305-8567, Japan

*Corresponding author. Tel: +81-11-706-2232; fax: +81-11-706-4867.

E-mail address: tusui@ees.hokudai.ac.jp (T. Usui). 


\section{Abstract}

Organic carbon $(\mathrm{C})$ and total nitrogen $(\mathrm{N})$ contents and corresponding isotope ratios were determined in surficial sediment $(0-3 \mathrm{~cm})$ at 94 stations ranging from 21 to 1995 m water depth off Tokachi, Hokkaido, Japan, to elucidate the distribution and source of sedimentary organic matter. Suspended particulate organic matter (POM) in the seawater and suspended POM and sediment in the Tokachi River were also examined. $\delta^{13} \mathrm{C}, \delta^{15} \mathrm{~N}$ and $\mathrm{C} / \mathrm{N}$ ratios of the samples in the Tokachi River suggest that the spring snowmelt is an important process for the transport of terrestrial organic matter to the coastal waters. $\delta^{13} \mathrm{C}$ values of suspended POM in the surface seawater were higher in May and November than in August, while $\delta^{15} \mathrm{~N}$ values of the POM were higher in May and August than in November. These changes are attributed to seasonal changes in phytoplankton growth rate and nitrate availability. $\delta^{13} \mathrm{C}$ and $\delta^{15} \mathrm{~N}$ values in the sediments off Tokachi were lowest near the Tokachi River mouth, and increased offshore to constant values that persisted from 134 to $1995 \mathrm{~m}$ water depth. The spatial variation in $\mathrm{C} / \mathrm{N}$ ratios in the sediment mirrored those of $\delta^{13} \mathrm{C}$ and $\delta^{15} \mathrm{~N}$. Comparison of $\delta^{13} \mathrm{C}, \delta^{15} \mathrm{~N}$ and $\mathrm{C} / \mathrm{N}$ ratios in the sediments off Tokachi with those in the Tokachi River and seawater indicates that about half of the organic matter in the sediment was of terrestrial origin near the Tokachi River mouth, and the sedimentary organic matter from 134 to 1995 m water depth was of marine origin. The organic $\mathrm{C}$ content in the sediment was high near the Tokachi River mouth, and also around $1000 \mathrm{~m}$ water depth. The C content was significantly correlated with silt plus clay content, with different regression lines for those stations shallower and deeper than $134 \mathrm{~m}$, owing to several stations of higher $\mathrm{C}$ content with the elevated $\mathrm{C} / \mathrm{N}$ ratio on the inner shelf. These results suggest that transport and deposition of organic-rich fine sediment particles by hydrodynamic processes were major factors 
controlling $\mathrm{C}$ content off Tokachi. In addition, the supply of a fraction of terrestrial organic matter with high $\mathrm{C} / \mathrm{N}$ probably also affected $\mathrm{C}$ content on the inner shelf.

\section{Keywords}

Carbon isotope; Nitrogen isotope; $\mathrm{C} / \mathrm{N}$ ratio; Sediment; Suspended particle; Grain size

\section{Regional index terms}

Western North Pacific; Japan; Hokkaido; Tokachi River

\section{Introduction}

Preservation of organic carbon (C) in marine sediments and subsequent incorporation into sedimentary rocks represent the predominant long-term sink in the global $\mathrm{C}$ cycle, and contribute to the formation and maintenance of an oxygenated atmosphere (Hedges and Keil, 1995). The burial of organic $\mathrm{C}$ in the ocean is estimated to

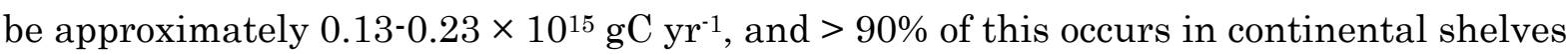
and slopes (Hedges and Keil, 1995; Wollast, 1998; de Haas et al., 2002). However, these estimations require further refinement because of the large temporal and spatial heterogeneity in continental margin sediments (Hedges and Keil, 1995; de Haas et al., 2002). Researches on the distribution and behavior of sedimentary organic matter in various shelf seas would help to improve estimates.

In the coastal regions, organic matter can be supplied both from marine organisms and terrestrial sources. Identifying the source materials in the sediment is essential to understand the mechanisms of $\mathrm{C}$ cycling in the marine environment. Based on the difference of the values among the sources, stable $\mathrm{C}$ and nitrogen $(\mathrm{N})$ isotope ratios and $\mathrm{C} / \mathrm{N}$ have been widely used to elucidate the source and fate of organic matter in the 
marine environment (Hedges and Parker, 1976; Peters et al., 1978; Fry and Sherr, 1984; Wada et al., 1987; Thornton and McManus, 1994; Ogawa and Ogura, 1997; Middelburg and Nieuwenhuize, 1998; Tyson, 1995; Naidu et al., 2000; Cloern et al., 2002; Gordon and Goñi, 2003; Goñi et al., 2003). However, it should be noted that $\mathrm{C}$ and $\mathrm{N}$ isotopic compositions and $\mathrm{C} / \mathrm{N}$ ratios in marine and riverine particulate organic matter (POM) often vary seasonally (Altabet et al., 1991; Mook and Tan, 1991; Nakatsuka et al., 1992; Tyson, 1995; Kendall et al., 2001; Nakanishi and Minagawa, 2003). While reliable estimates of sedimentary organic matter sources should take into account such seasonal variations, there have only been limited numbers of studies addressing this issue (Cifuentes et al., 1988; Ogawa and Ogura, 1997; Gordon and Goñi, 2003; Goñi et al., 2003).

In this study, we measured organic $\mathrm{C}$ and total $\mathrm{N}$ contents and their isotope ratios in the surface sediment from inner shelf to slope off the coast of Tokachi, southeast Hokkaido, Japan. In addition, suspended POM in the seawater and the Tokachi River, which were collected in various seasons, and the sediment of the Tokachi River were examined to define isotope and $\mathrm{C} / \mathrm{N}$ ratios of terrestrial and marine sources. Using these data, we discuss the origin of organic matter in the sediment off Tokachi and the mechanisms regulating the distribution of the sedimentary organic matter.

\section{Materials and methods}

\subsection{Study site}

The Tokachi River (156 km length) flows through the Tokachi plains and empties into the western North Pacific (Fig. 1). River flow increases in spring and early fall (Ministry of Land, Infrastructure and Transport, Japan, 
http://www.mlit.go.jp/river/english/), due to snowmelt and an increase of precipitation, respectively.

The Oyashio current, which originates in the western subarctic gyre in the North Pacific and partly in the Sea of Okhotsk, flows southwestward off the southeast coast of Hokkaido (Kawai, 1972). An alongshore current originating in the Sea of Okhotsk also flows southwestward on the shelf of southeast Hokkaido (Ohtani, 1971, 1991). The Mixed Water, which is the mixture of the Oyashio Water and the subtropical water originating in the Kuroshio Current, is occasionally observed off southeast Hokkaido (Kawai, 1972). The temperature at $100 \mathrm{~m}$ depth in each month $\left(5\right.$ to $\left.8^{\circ} \mathrm{C}\right)$ is used as a definition of the front between the Oyashio and the Mixed Water (Kawai, 1972; Limsakul et al., 2002). According to the database of Japan Oceanographic Data Center (http://www.jodc.go.jp/), the mean plus $1 \mathrm{s.d}$. of temperature at $100 \mathrm{~m}$ depth obtained in the two grids of $42-43^{\circ} \mathrm{N}$ and $143-144^{\circ} \mathrm{E}$ or $144-145^{\circ} \mathrm{E}$ from 1903 to $2003(\mathrm{n}=9$ to 567 in each month) are below the definition, except that the temperature of $7.18^{\circ} \mathrm{C}$ in the grid of $42-43^{\circ} \mathrm{N}$ and $144-145^{\circ} \mathrm{E}$ in October is slightly higher than the definition of $7^{\circ} \mathrm{C}$. Thus the Oyashio is a dominant water mass in our site. In the Oyashio, intensive phytoplankton blooms of diatoms occur in April and May, and relatively small blooms are observed in October (Limsakul et al., 2002). On the other hand, blooms do not occur in the Mixed Water (Kasai et al., 1997; Saito et al., 1998).

\subsection{Sample collection}

Sediments were collected using a K-Grab sampler during the GH02 cruise of R/V Hakurei-maru No.2 in August 2002 and using a multiple core sampler "Ashura” (Rigo Co., Ltd.) during the cruises of T/S Ushio-maru in May, August and November 2003 off 
Tokachi (Fig. 1, Table 1). The surface sediment samples (top $3 \mathrm{~cm}$ depth) were stored at $-30^{\circ} \mathrm{C}$. During the cruises of T/S Ushio-maru, seawater samples were collected using a CTD/rosette multi-sampler system with Niskin bottles at Stn. T-35 $\left(42^{\circ} 26.0^{\prime} \mathrm{N}, 143^{\circ} 59.5^{\prime} \mathrm{E}\right.$, $567 \mathrm{~m}$ water depth).

Surface water samples of the Tokachi River were collected at Stn. Moiwa, ca. $20 \mathrm{~km}$ upstream of the river mouth (Fig. 1), in April, May, June, July, August, September and November 2003. There are no major tributaries or wastewater inputs between Stn. Moiwa and the river mouth. In August 2003, surface waters and sediments were sampled at three estuarine stations located at $4.8 \mathrm{~km}$ (Stn. Kako-1), $820 \mathrm{~m}$ (Stn. Kako-2) and 240 m (Stn. Kako-3) upstream of the river mouth. An Ekman-Birge grab sampler was used to collect the sediment of the top $5 \mathrm{~cm}$ depth. Temperature, electric conductivity (EC), salinity and turbidity in the waters were measured by portable sensors (U-21XD, Horiba Ltd., Japan). Turbidity was determined by the light-transmission`scattering method.

After pre-filtration using a $315 \mu \mathrm{m}$ mesh net, the samples of seawater and river water were filtered through precombusted $\left(450^{\circ} \mathrm{C} 3 \mathrm{hrs}\right)$ Whatman $\mathrm{GF} / \mathrm{F}$ filters for POM analysis. The filters were stored at $-20^{\circ} \mathrm{C}$ until analysis. Samples for chlorophyll a determination were collected using $\mathrm{GF} / \mathrm{F}$ filters and stored at $-20^{\circ} \mathrm{C}$ in the dark after soaking with $N, N$-dimethylformamide (Suzuki and Ishimaru, 1990). Unfiltered seawater samples at Stn. T-35 were kept in screw-capped test tubes at $-20^{\circ} \mathrm{C}$ for nutrient analysis.

\subsection{Analyses}

The sediment samples for $\mathrm{C}$ and $\mathrm{N}$ analyses were dried at $60^{\circ} \mathrm{C}$, decarbonated by $1 \mathrm{M} \mathrm{HCl}$, rinsed with distilled deionized water, and dried again. The suspended POM samples were dried at $60^{\circ} \mathrm{C}$ and acidified with vapor of $12 \mathrm{M} \mathrm{HCl}$. The $\mathrm{C}$ and $\mathrm{N}$ contents 
and their isotope ratios in the sedimentary organic matter and suspended POM were determined using an isotope ratio mass spectrometer equipped with an elemental analyzer (Fisons NA1500 - Finnigan MAT 252). A part of the samples were analyzed by another mass spectrometer (Flush EA - Finnigan MAT DELTA plus XP). The isotope ratios are expressed as per-mil (\%o) notation:

$$
\begin{aligned}
& \delta^{13} \mathrm{C}=\left\{\left({ }^{13} \mathrm{C} /{ }^{12} \mathrm{C}\right)_{\text {sample }} /\left({ }^{13} \mathrm{C} /{ }^{12} \mathrm{C}\right)_{\text {standard }}-1\right\} \times 1000 \\
& \delta^{15} \mathrm{~N}=\left\{\left(15 \mathrm{~N} /{ }^{14} \mathrm{~N}\right)_{\text {sample }} /\left({ }^{15} \mathrm{~N} /{ }^{14} \mathrm{~N}\right)_{\text {standard }}-1\right\} \times 1000 .
\end{aligned}
$$

Data are presented as the values based on the international standard of PDB and atmospheric $\mathrm{N}_{2}$ for $\mathrm{C}$ and $\mathrm{N}$, respectively. The replicate error was within $\pm 0.2 \%$ for both $\delta^{13} \mathrm{C}$ and $\delta^{15} \mathrm{~N}$ analyses.

For the sediments collected during GH02 cruise, grain size distribution was determined by the combined sieving-hydrometer method (Krumbein and Pettijohn, 1938).

Chlorophyll a concentrations in seawater and river water were analyzed by fluorometry (Parsons et al., 1984) and by high-performance liquid chromatography (Suzuki et al., 2005), respectively. Nitrate and nitrite concentrations in seawater were determined by the method of Strickland and Parsons (1972) with a slight modification for the autoanalyzer.

\section{Results}

\subsection{Suspended particles and sediments of the Tokachi River}

Rainfall over the 10 days prior to each sampling date of the Tokachi River was in the range of 12 to $36 \mathrm{~mm}$ (Table 2), indicating that our samples were not collected after heavy rain events. Turbidity at Stn. Moiwa was higher in April, May and September than on other occasions. Increases of suspended particulate organic carbon (POC) and 
particulate nitrogen $(\mathrm{PN})$ concentrations were also observed in April and September. The $\mathrm{C} / \mathrm{N}$ ratio of suspended POM at Stn. Moiwa was higher in April and May (12.2-14.9) than in June to November (6.5-8.8). On the other hand, no clear pattern of seasonal variation was observed for $\delta^{13} \mathrm{C}$ and $\delta^{15} \mathrm{~N}$ values of the POM.

At the estuarine stations in August, salinity were $<1$ in the surface waters and increased below 2-4 m water depth, reaching 14-26 in bottom waters at 4-6.5 m depth. Slight increases of POC and PN concentrations were observed from Stn. Moiwa to the estuary in August (Table 2). Turbidity and chlorophyll a were also higher in the estuary than at Stn. Moiwa. A decrease of $\delta^{13} \mathrm{C}-\mathrm{POC}$ and an increase of $\delta^{15} \mathrm{~N}-\mathrm{PN}$ values were observed from Stn. Moiwa to the estuary, while the $\mathrm{C} / \mathrm{N}$ did not change significantly.

$\delta^{13} \mathrm{C}, \delta^{15} \mathrm{~N}$ and $\mathrm{C} / \mathrm{N}$ values in the estuarine sediments were different from those of suspended POM in the estuary in August, but were similar to those of suspended particles at Stn. Moiwa in April and May (Table 2).

\subsection{Suspended particles in seawater off Tokachi}

The salinity distribution indicates that the plume of the Tokachi River water was restricted within half of the distance between the river mouth and Stn. T-35 during the cruises of T/S Ushio-maru (Taira, unpublished). Temperatures at $100 \mathrm{~m}$ depth of Stn. T-35 (Table 3) were lower than the definition the Oyashio front $\left(5,6\right.$ and $8^{\circ} \mathrm{C}$ in May, August and November, respectively: Kawai, 1972), indicating that Stn. T-35 was located in the Oyashio Water.

The vertical density gradient near sea surface at Stn. T-35 increased from May to August due to the rise of temperature, and it decreased in November, indicating the occurrence of autumnal mixing (Fig. 2). Nitrate plus nitrite (hereafter nitrate) in surface 
water was mostly depleted in May and August. An increase of surface nitrate was observed in November. Chlorophyll a concentrations in the water column were highest in May. Concentrations decreased in August and increased again in November. The peaks of suspended POC and PN concentrations were observed at 0-10 m depth and decreased with water depth. The POC and PN concentrations at 0-100 m depth decreased from May to August, whereas an increase in concentration was observed in November. $\delta^{13} \mathrm{C}-\mathrm{POC}$ was highest in the surface layer and decreased with water depth. $\delta^{15} \mathrm{~N}-\mathrm{PN}$ decreased from the surface to $20-40 \mathrm{~m}$ depth and increased to a maximum at $100-500 \mathrm{~m}$ depth. The $\mathrm{C} / \mathrm{N}$ ratio increased with water depth. $\delta^{13} \mathrm{C}-\mathrm{POC}$ in the water column decreased from May to August and increased again in November near the value of May. The $\delta^{15} \mathrm{~N}-\mathrm{PN}$ at $0-10 \mathrm{~m}$ depth did not change from May to August, and decreased in November. The ratio of POC/chlorophyll $a$ in the water column was higher in August than in May and November.

\subsection{Sediments off Tokachi}

There were two areas that exhibited maxima in sedimentary organic C (Fig. 3). One was immediately south of the Tokachi River mouth on the inner shelf, and another was around $1000 \mathrm{~m}$ water depth line on the slope. The distribution patterns of total $\mathrm{N}$ and silt plus clay $(<62.5 \mu \mathrm{m})$ in the sediment were similar to that of organic C (Fig. 4). $\delta^{13} \mathrm{C}$ of organic $\mathrm{C}$ and $\delta^{15} \mathrm{~N}$ of total $\mathrm{N}$ in the sediment were lowest south of the Tokachi River mouth on the inner shelf, and increased offshore and in the surrounding areas (Figs. 5 and 6 ). The $\delta^{13} \mathrm{C}$ and $\delta^{15} \mathrm{~N}$ values were approximately constant from 134 to $1995 \mathrm{~m}$ depth. The distribution pattern of $\mathrm{C} / \mathrm{N}$ ratios was a mirror image of $\mathrm{C}$ and $\mathrm{N}$ isotopes (Fig. 7). The distributions of $\delta^{13} \mathrm{C}, \delta^{15} \mathrm{~N}$ and $\mathrm{C} / \mathrm{N}$ generally corresponded to each other, but the stations exhibiting peak values on the inner shelf were different (Figs. 5 to 
7).

Figs. 8a and $8 \mathrm{~b}$ show $\delta^{13} \mathrm{C}-\delta^{15} \mathrm{~N}$ and $\delta^{13} \mathrm{C}-\mathrm{C} / \mathrm{N}$ plots of the samples analyzed in this study, respectively. The range of $\delta^{13} \mathrm{C}$ and $\delta^{15} \mathrm{~N}$ values in seawater POM at 0-10 $\mathrm{m}$ depth overlapped generally with the sediments off Tokachi and were higher than the river samples. Decreases of $\delta^{13} \mathrm{C}$ and $\delta^{15} \mathrm{~N}$ and increase of $\mathrm{C} / \mathrm{N}$ were observed in the sediments shallower than $134 \mathrm{~m}$ water depth compared with those from 134 to $1995 \mathrm{~m}$ depth. Suspended POM at Stn. Moiwa in April and May and the estuarine sediments exhibited lower $\delta^{13} \mathrm{C}$ and $\delta^{15} \mathrm{~N}$ values and higher $\mathrm{C} / \mathrm{N}$ ratios than the sediments off Tokachi.

\section{Discussion}

4.1. Seasonal and spatial variations of $\delta^{13} \mathrm{C}, \delta^{15} \mathrm{~N}$ and $\mathrm{C} / \mathrm{N}$ of suspended POM in the Tokachi River

The flooding of the river by the snowmelt was probably responsible for the increase of suspended POM concentration at Stn. Moiwa in April (Table 2). The elevated value in September may be attributed to the increased river flow due to $15 \mathrm{~mm}$ of rainfall on the day before the sampling.

Suspended POM in rivers exhibits $\delta^{13} \mathrm{C}$ of -37 to $-18 \%$, $\delta^{15} \mathrm{~N}$ of -15 to $14 \%$ and the molar C/N ratios of 4 to 40 (Meybeck, 1982; Fry and Sherr, 1984; Wada et al., 1987; Mook and Tan, 1991; Bird et al., 1995; Ogawa and Ogura, 1997; Middelburg and Nieuwenhuize, 1998; Kendall et al., 2001; Cloern et al., 2002; Hein et al., 2003; Kao et al., 2003). The values in the Tokachi River (Table 2) were within these ranges. Major sources of suspended POM in rivers are $\mathrm{C} 3$ and/or $\mathrm{C} 4$ vascular plants, soil organic matter and 
phytoplankton. According to a review of Kendall et al. (2001), the mean and general range of $\delta^{13} \mathrm{C}$ of $\mathrm{C} 3$ plants and organic matter in $\mathrm{C} 3$ plant-dominated soil, $\mathrm{C} 4$ plants and organic matter in $\mathrm{C} 4$ plant-dominated soil, and freshwater phytoplankton are $-27 \%$ (-32 to $-22 \%$, $-13 \%$ (-16 to $-9 \%)$, and $-30 \%$ ( -42 to $-24 \%$ ), respectively. ${ }^{13} \mathrm{C}-\mathrm{POC}$ in the Tokachi River ranged from -28.8 to $-25.2 \%$ (Table 2 ), suggesting that contributions from the C4-based vascular plant organic matter was negligible. The molar $\mathrm{C} / \mathrm{N}$ ratios in vascular plants, soil, and riverine phytoplankton are generally $>15,8$ to 15 , and 5 to 8 , respectively (Kendall et al., 2001). Because the C/N ratios of suspended POM at Stn. Moiwa were 12.2-14.9 in April and May and 6.5-8.8 from June to November (Table 2), the major source of POM was probably vascular plants and/or soil having a high $\mathrm{C} / \mathrm{N}$ ratio in spring, and phytoplankton and/or soil having low $\mathrm{C} / \mathrm{N}$ ratio in summer and fall.

The increase of chlorophyll a from Stn. Moiwa to the estuarine stations indicates the occurrence of POM production by phytoplankton in August (Table 2). The corresponding changes of $\delta^{13} \mathrm{C}$ and $\delta^{15} \mathrm{~N}$ of POM from Stn. Moiwa to the estuary likely resulted from POM production in the river. Although the data obtained in August suggest that POM production occurred from Stn. Moiwa to the estuary, its contribution is likely to be minor. Even in August when water temperature was highest in the year and it was not a storm flow condition, the POM concentration increased only slightly (Table 2).

\section{2. $\delta^{13} \mathrm{C}, \delta^{15} \mathrm{~N}$ and $\mathrm{C} / \mathrm{N}$ of POM supplied from the Tokachi River to the coastal waters}

The $\mathrm{C} / \mathrm{N}$ ratio of the suspended POM and the estuarine sediment in the Tokachi River (Fig. 8b) suggest that the former was a major source of organic matter in the estuarine sediment in April and May. However, alternation of $\mathrm{C} / \mathrm{N}$ ratios during the organic matter decomposition should be considered. Organic $\mathrm{N}$ is generally remineralized 
faster than organic $\mathrm{C}$, which serves to increase $\mathrm{C} / \mathrm{N}$ ratios (Tyson, 1995). On the other hand, if organic matter with high $\mathrm{C} / \mathrm{N}$ is degraded under conditions of surplus inorganic $\mathrm{N}$, the $\mathrm{C} / \mathrm{N}$ can decrease due to $\mathrm{N}$ immobilization to supply the relative $\mathrm{N}$-deficit in the substrate (Tyson, 1995). The former can increase $\mathrm{C} / \mathrm{N}$ during the decomposition of nitrogenous planktonic organic matter (Lehmann et al., 2002). The latter prevails during the decomposition of vascular plants of high initial $\mathrm{C} / \mathrm{N}$ in $\mathrm{N}$-rich coastal environment (Benner et al., 1991). Tyson (1995) reported that the molar $\mathrm{C} / \mathrm{N}$ ratios of fresh vascular plants and their degraded detritus were 23-1560 and 14-47, respectively. Molar C/N in soils generally ranges from 8 to 15 (Kendall et al., 2001), which is also likely due to the $\mathrm{C} / \mathrm{N}$ of well-degraded organic matter originating in vascular plants. Because suspended POM with $\mathrm{C} / \mathrm{N}$ of 12.2-14.9 at Stn. Moiwa in spring (Table 2) was probably derived from degraded plant detritus and/or soil (see section 4.1), the $\mathrm{C} / \mathrm{N}$ of the POM likely changed only slightly after the settling to the estuarine sediment. It is likely also true of the fraction in suspended POM originating in soil from June to November. On the other hand, part of suspended POM from June to November likely derived from phytoplankton, and $\mathrm{C} / \mathrm{N}$ ratios might therefore increase during early diagenesis. However, because the $\mathrm{C} / \mathrm{N}$ of the sedimentary organic matter of marine origin in shelves and slopes generally ranges from 6 to 14 (Tyson, 1995), it is unlikely that the $\mathrm{C} / \mathrm{N}$ of POM from phytoplankton in the Tokachi River increased to the levels (14.3-19.3) in the estuarine sediments underlying saline bottom water. We therefore conclude that the major source of sedimentary organic matter in the Tokachi River Estuary was not planktonic POM, but rather the detritus of C3 vascular plants and/or corresponding soil organic matter. The lack of a significant increase in suspended POM concentrations from St. Moiwa to the estuary in August (see section 4.1) also supports this inference. The C3 plant derived POM was presumably transported from the watershed during the flood by the spring snowmelt. This process is 
probably also important for POM loading from the Tokachi River to the coastal sediment.

$\delta^{13} \mathrm{C}$ and $\delta^{15} \mathrm{~N}$ values of POM can change by post-production processes including the preferential removal of organic compounds with different isotope ratios from bulk POM, ${ }^{13} \mathrm{C}$ and ${ }^{15} \mathrm{~N}$ enrichments in the residual POM during degradation, transformations through the food chain, and/or the immobilization of ambient $\mathrm{N}$ with different $\delta^{15} \mathrm{~N}$ from the POM (Benner et al., 1987, 1991; Michener and Schell, 1994; Lehmann et al., 2002). However, $\delta^{13} \mathrm{C}$ and $\delta^{15} \mathrm{~N}$ values in the estuarine sediments in the Tokachi River were close to those of suspended POM in May and within the range of suspended POM observed in the Tokachi River (Fig. 8a). Therefore the changes of $\delta^{13} \mathrm{C}$ and $\delta^{15} \mathrm{~N}$ of POM during settling and diagenesis were probably of limited extent in the Tokachi River.

\subsection{Vertical and seasonal changes of $\delta^{13} \mathrm{C}, \delta^{15} \mathrm{~N}$ and $\mathrm{C} / \mathrm{N}$ of suspended POM off Tokachi}

The maximum concentration of suspended POM was observed in the surface layer (0-10 m depth), and its level decreased with depth at Stn. T-35 (Fig. 2). Similar patterns were also reported in previous ocean studies (Saino and Hattori, 1980, 1987; Altabet, 1988; Altabet et al., 1991; Minagawa et al., 2001), which is a reflection that POM production mainly occurs in the surface layer and the POM degradation occurs below the surface (Suess, 1980).

$\delta^{13} \mathrm{C}-\mathrm{POC}$ of -26.1 to $-18.8 \%$ and $\delta^{15} \mathrm{~N}-\mathrm{PN}$ of 3.7 to $6.9 \%$ at $0-10 \mathrm{~m}$ depth at Stn.

T-35 (Fig. 2) were within the range (-28 to $-12 \%$ and -1.5 to $19 \%$, respectively) reported in surface water at middle latitude in the northern hemisphere (Rau et al., 1982, 1998, 2001; Saino and Hattori, 1985, 1987; Altabet, 1989; Altabet et al., 1991; Saino, 1992; Goericke and Fry, 1994; Minagawa et al., 2001; Mino et al., 2002). The $\mathrm{C} / \mathrm{N}$ of 5.6 to 9.9 at 0-10 m depth fell within the range of plankton of 5-12 (Tyson, 1995). POC/chlorophyll a 
ratio at 0-10 m depth in May (47.6-56.3) and November (58.1-77.5) were within the range of phytoplankton (20-120) (Geider, 1987; Thompson et al., 1992). On the other hand, the ratios in August (243-547) indicate an increase of non-phytoplankton organic particles.

Lower $\delta^{13} \mathrm{C}$ values in suspended POC in August and at deeper layer in May and November at Stn. T-35 (Fig. 2) were similar to the values in the Tokachi River (-28.8 to $-25.2 \%$ ). By the comparison of both $\delta^{13} \mathrm{C}$ and $\delta^{15} \mathrm{~N}$, however, only the values at $150-500 \mathrm{~m}$ depth in May and at 30-50 m depth in August at Stn. T-35, which were $\delta^{13} \mathrm{C}$ of $<-24 \%$ and $\delta^{15} \mathrm{~N}$ of $<5 \%$, were close to the river samples (Figs. 2 and $8 \mathrm{a}$ ). Therefore, marine organic matter was presumably major component of suspended POM at Stn. T-35, except for the above samples for which we cannot rule out the possibility of terrestrial organic matter contributions.

The patterns of vertical change of $\delta^{13} \mathrm{C}, \delta^{15} \mathrm{~N}$ and $\mathrm{C} / \mathrm{N}$ in this study (Fig. 2) were consistent to those reported in previous ocean studies (Eadie and Jeffrey, 1973; Saino and Hattori, 1980, 1985, 1987; Altabet, 1988; Altabet et al., 1991; Saino, 1992; Tyson, 1995; Voss et al., 1996; Wu et al., 1999; Minagawa et al., 2001). The occurrence of a subsurface $\delta^{15} \mathrm{~N}-\mathrm{PN}$ minimum has been interpreted as the result of a large isotope fractionation during $\mathrm{N}$ assimilation under light-limited $\mathrm{N}$-replete condition in the subsurface layer (Saino and Hattori, 1985; Altabet et al., 1986). The changes of $\mathrm{C} / \mathrm{N}$ and isotope ratios at deeper layer likely resulted from the post-production processes as mentioned in section 4.2.

In May, nitrate in surface water at Stn. T-35 was mostly depleted while surface chlorophyll a showed a high value of $13.6 \mu \mathrm{g} \mathrm{l}^{-1}$ (Fig. 2), suggesting that the water was in the late stage of spring bloom. In August, nitrate depletion and low chlorophyll a concentration in the surface water were probably due to summer stratification. Increases in nitrate and chlorophyll $a$ in the surface layer in November suggest that vertical mixing 
in fall supplied nutrients and stimulated the growth of phytoplankton.

The $\delta^{13} \mathrm{C}$ values of surface POC at Stn. T-35 were higher in May and November than in August (Fig. 2). When the growth rate of phytoplankton increases and/or dissolved molecular $\mathrm{CO}_{2}$ concentration decreases, heavy $\delta^{13} \mathrm{C}-\mathrm{POC}$ is produced because of a decrease in isotope fractionation during C fixation (Takahashi et al., 1991; Rau, 1994; Laws et al., 1995). In May and November, elevated phytoplankton growth during spring and autumn blooms thus probably accounted for heavy $\mathrm{C}$ isotope ratios. Although dissolved molecular $\mathrm{CO}_{2}$ was not determined in this study, its decrease due to elevated phytoplankton growth could also contribute to the rise of $\delta^{13} \mathrm{C}-\mathrm{POC}$. Phytoplankton growth in August may have been suppressed by low nutrient availability, resulting in the decrease of $\delta^{13} \mathrm{C}$-POC. Although the increase of non-phytoplankton particles such as detritus and heterotrophs in August may have affected $\delta^{13} \mathrm{C}-\mathrm{POC}$ due to the $\delta^{13} \mathrm{C}$ changes during POC degradation and $\delta^{13} \mathrm{C}$ increase through food chain (see section 4.2), these effects were not apparently observed.

$\delta^{15} \mathrm{~N}$ in surface PN at Stn. T-35 was higher in May and August than in November (Fig. 2). Availability of nitrate is an important factor controlling the isotope ratio of PN produced in the ocean (Altabet and Francois, 1994; Montoya, 1994). At the onset of the bloom when surface nitrate is not significantly consumed, phytoplankton biomass is depleted in ${ }^{15} \mathrm{~N}$ relative to nitrate existing initially in the surface layer because of isotope fractionation during $\mathrm{N}$ assimilation (Montoya, 1994). The $\delta^{15} \mathrm{~N}$ in phytoplankton increases as the nitrate pool is depleted due to the increase of $\delta^{15} \mathrm{~N}$ in residual nitrate. When the substrate (nitrate) is completely exhausted, $\delta^{15} \mathrm{~N}$ of the product (suspended plus sinking $\mathrm{PN}$ ) integrated throughout the reaction reaches the same value as the initial substrate (nitrate). Therefore, the higher $\mathrm{N}$ isotope ratio in surface $\mathrm{PN}$ in May at Stn. T-35 was probably attributed to nitrate depletion in the late stage of spring bloom. 
Although $\delta^{15} \mathrm{~N}$ of suspended PN in stratified surface water can be altered by grazing, degradation and/or incorporation of $\mathrm{PN}$ by heterotrophs, $\mathrm{PN}$ removal via sinking particles, and PN production from regenerated ammonium (Altabet and Francois, 1994; Michener and Schell, 1994; Montoya, 1994), their influences appear to be of limited extent from May to August off Tokachi. Nitrate was probably supplied continuously to the surface layer by autumnal mixing, which presumably accounts for the decrease of $\delta^{15} \mathrm{~N}-\mathrm{PN}$ in November via isotope fractionation during $\mathrm{N}$ assimilation.

The seasonal variation of isotope and $\mathrm{C} / \mathrm{N}$ ratios in suspended POM below the surface layer (Fig. 2) might result from the propagation of the change in the nature of POM produced in the surface layer via sinking particles.

\subsection{Estimation of $\delta^{13} \mathrm{C}$ and $\delta^{15} \mathrm{~N}$ in sinking POM off Tokachi}

The Oyashio is a dominant water mass off Tokachi (see section 2.1). Intensive phytoplankton blooms occur in the Oyashio, but not in the Mixed Water (Kasai et al., 1997; Saito et al., 1998). Therefore, POM production in the Oyashio, in which our samples were obtained, would be the major process regulating $\delta^{13} \mathrm{C}$ and $\delta^{15} \mathrm{~N}$ in POM off Tokachi.

Because our data were obtained both during high productivity periods (with high ${ }^{13} \mathrm{C}-\mathrm{POC}$ in spring and fall blooms) and a low productivity period (with low $\delta^{13} \mathrm{C}-\mathrm{POC}$ in summer stratification), the annual mean $\delta^{13} \mathrm{C}-\mathrm{POC}$ in the surface layer of Stn. T-35 weighted for POC concentration was likely to fall within the range obtained in this study (Fig. 8a). Although $\delta^{13} \mathrm{C}-\mathrm{POC}$ at another low productivity period in winter could be lower than that in summer, its influence might be of limited extent because the suspended POC concentration would also be low. Vertical POM transport in the ocean is mostly mediated by rapidly sinking larger particles, but not by slowly sinking smaller particles, i.e., 
suspended POM (Suess, 1980). Nakatsuka et al. (1992) showed that $\delta^{13} \mathrm{C}$ of sinking POC collected just below the surface layer (16 $\mathrm{m}$ depth) was similar to that of surface-suspended POC during the bloom experiment in a mesocosm. Lourey et al. (2004) reported that sinking $\mathrm{POC}$ had ${ }^{13} \mathrm{C}$ values similar to surface-suspended $\mathrm{POC}$ in the period of high sinking flux in the subantarctic waters, while the $\delta^{13} \mathrm{C}$ of the sinking POC became higher than that of suspended POC in the low flux period. They showed that the weighted mean $\delta^{13} \mathrm{C}$ value of sinking POC at $1060 \mathrm{~m}$ was $1.5 \%$ higher than that of surface-suspended POC from September and February (austral spring to summer). Therefore, averaged $\delta^{13} \mathrm{C}$ of sinking POC may also have been $1.5 \%$ higher than that of surface-suspended POC off Tokachi.

In phytoplankton blooms in the ocean, $\delta^{15} \mathrm{~N}$ of the integrated product (suspended plus sinking $\mathrm{PN}$ ) becomes equal to the value of the substrate (nitrate) when nitrate is completely consumed (Montoya, 1994). If part of PN is removed from the surface layer via sinking PN before all nitrate is converted to $\mathrm{PN}, \delta^{15} \mathrm{~N}$ of $\mathrm{PN}$ left in the surface layer when nitrate is depleted should be higher than the initial nitrate, because of the removal of ${ }^{15} \mathrm{~N}$-depleted sinking PN. Hence, $\delta^{15} \mathrm{~N}$ of nitrate consumed in the surface layer at $\mathrm{Stn}$. T-35 was presumably lower than, or equal to, the value of the surface-suspended PN at late stage of spring bloom (i.e. in May). Because phytoplankton probably grow under a nitrate-replete condition in November, it is likely that the $\delta^{15} \mathrm{~N}$ of surface-suspended PN was lower than the nitrate owing to the isotope fractionation. Therefore, $\delta^{15} \mathrm{~N}$ of nitrate consumed at Stn. T-35 was presumably within the range from 3.7 to $6.9 \%$ (Fig. 8a). This estimated range is consistent with $\delta^{15} \mathrm{~N}$ of nitrate (6.3 to $6.8 \%$ ) measured in the intermediate water in the western subarctic North Pacific (Minagawa et al., 2001).

If surface nitrate is supplied by vertical mixing from fall to winter and is completely consumed in summer as in the present study, the annual mean $\delta^{15} \mathrm{~N}$ of PN 
sinking from the surface layer should be equal to that of the consumed nitrate (Altabet et al., 1999). According to historical data (Limsakul et al., 2002), however, the mean \pm s.d. of surface nitrate of the Oyashio was $0.8 \pm 1.7 \mu \mathrm{M}$ in August, i.e., it was not always depleted in summer. The average surface nitrate of the Oyashio in March, when the value became highest in a year, was $20.2 \mu \mathrm{M}$, implying that $96 \%$ of the nitrate supplied to the surface was consumed from spring to summer. Based on 1st order Raleigh fractionation kinetics (Altabet and Francois, 1994) and the fractionation factor of 2 to 12 during $\mathrm{N}$ assimilation by phytoplankton (Montoya, 1994), the $\delta^{15} \mathrm{~N}$ of the integrated product PN was estimated to be -1.6 to $-0.3 \%$ lower than the source nitrate when $96 \%$ of nitrate was consumed. Therefore, the $\delta^{15} \mathrm{~N}$ of the sinking $\mathrm{PN}$ was likely -1.6 to $0 \%$ lower than the range of surface-suspended PN.

\subsection{Source of sedimentary organic matter off Tokachi}

Since $\delta^{13} \mathrm{C}, \delta^{15} \mathrm{~N}$ and $\mathrm{C} / \mathrm{N}$ values in the estuarine sediments result from the integrated processes such as the transport, settling, and diagenesis of POM, it seems plausible that terrestrially-derived organic matter in the sediment off Tokachi had values similar to those of the estuarine sediment.

According to sediment trap observations in the ocean, both decreases and increases of $\delta^{13} \mathrm{C}$ values with water depth have been observed for sinking POC (Nakatsuka et al., 1997; Wu et al., 1999; Nakanishi and Minagawa, 2003; Lourey et al., 2004). Regarding $\delta^{15} \mathrm{~N}$ of sinking particles, both a decrease and negligible change with depth were reported (Altabet et al., 1991; Nakatsuka et al., 1997; Wu et al., 1999;

Nakanishi and Minagawa, 2003; Lourey et al., 2003). Because $\delta^{13} \mathrm{C}$ and $\delta^{15} \mathrm{~N}$ values in the sedimentary organic matter were near constant from 134 to 1995 m depth (Figs. 5 and 6), 
it is unlikely that $\mathrm{C}$ and $\mathrm{N}$ isotope ratios in sinking POM changed significantly with water depth off Tokachi.

According to the compilation of previous reports by Nakanishi and Minagawa (2003), $\delta^{13} \mathrm{C}$ and $\delta^{15} \mathrm{~N}$ values tend to increase from sinking POM to organic matter in surface sediment in the ocean. The mean \pm s.d. of the increases were $1.4 \pm 0.6 \%$ and $1.3 \pm$ $1.1 \%$, respectively, at sites of 1000-2200 m water depth with oxic bottom water. Although there have been no reports at the sites shallower than $1000 \mathrm{~m}$ water depth, the changes between sinking particles and sediment may be smaller than those at 1000-2200 m water depth because these changes are reduced with decreasing water depth.

Based on the change of $\delta^{13} \mathrm{C}$ from surface-suspended particles to sinking particles $(1.5 \%)$ estimated in section 4.4 and that from sinking particles to sediment $(<1.4 \%), \delta^{13} \mathrm{C}$ values of marine organic matter in the sediment off Tokachi was likely 1.5 to $2.9 \%$ higher than the value of surface-suspended POC (-26.1 to $-18.8 \%$ ), i.e., from -24.6 to $-15.9 \%$ (Fig. 8a). With respect to $\delta^{15} \mathrm{~N}$, the sum of the former $(-1.6$ to $0 \%$ ) and the latter $(<1.3 \%)$ changes was -1.6 to $1.3 \%$, so that $\delta^{15} \mathrm{~N}$ of marine organic matter in the sediment estimated from the value of surface-suspended PN (3.7 to $6.9 \%$ ) was 2.1 to $8.2 \%$ (Fig. $8 \mathrm{a}$ ). The $\mathrm{C} / \mathrm{N}$ ratio tends to increase while POM sinks through the water column in the ocean (Schneider et al., 2003). Also, during diagenesis in the sediment, the $\mathrm{C} / \mathrm{N}$ ratio can increase as mentioned in section 4.2. However, because the $\mathrm{C} / \mathrm{N}$ ratio in the sediment was constant from 134 to $1995 \mathrm{~m}$ water depth and was similar to the values of surface-suspended POM (Figs. 7 and 8b), it is unlikely that the $\mathrm{C} / \mathrm{N}$ ratio significantly altered during particle sinking and early diagenesis in our study site.

The plots of $\delta^{13} \mathrm{C}$ vs. $\delta^{15} \mathrm{~N}$ and $\delta^{13} \mathrm{C}$ vs. C/N (Fig. 8) indicate that there were two sources of the sedimentary organic matter off Tokachi. The relationship of $\delta^{13} \mathrm{C}, \delta^{15} \mathrm{~N}$ and $\mathrm{C} / \mathrm{N}$ between the sediment and the estimated values of terrestrial and marine sources 
suggest that terrestrial organic matter was supplied from the Tokachi River to the inner shelf sediment in addition to the supply of organic matter from marine primary production, and the sedimentary organic matter from 134 to $1995 \mathrm{~m}$ water depth was of marine origin. The horizontal distributions of $\delta^{13} \mathrm{C}, \delta^{15} \mathrm{~N}$ and $\mathrm{C} / \mathrm{N}$ in the sediment off Tokachi also support this interpretation (Figs. 5 to 7).

The signals of terrestrial organic matter were strongest south of the Tokachi River mouth, rather than perpendicular to the shoreline (Figs. 5 to 7), presumably as a result of an alongshore current flowing southwestward over the shelf (Ohtani, 1971, 1991).

Although spatial patterns of $\delta^{13} \mathrm{C},{ }^{15} \mathrm{~N}$ and $\mathrm{C} / \mathrm{N}$ showed strong co-variation, the station exhibiting the highest value was different for each parameter (Figs. 5 to 7 ). The discrepancy suggests that terrestrially-derived POM was heterogeneous, and the deposition and decomposition of these particles on the shelf probably fluctuated depending on their specific characteristics.

Using the averages of $\delta^{13} \mathrm{C}, \delta^{15} \mathrm{~N}$ and $\mathrm{C} / \mathrm{N}$ values in three estuarine sediments $(-26.9 \%, 2.3 \%$ and 16.4 , respectively) and those in the sediments from 134 to $1995 \mathrm{~m}$ water depth $(-21.0 \%, 5.9 \%$ and 8.4 , respectively) as terrestrial and marine end members, respectively, we calculated the fraction of terrestrial material in sedimentary organic matter at the stations with the lowest $\delta^{13} \mathrm{C}(\mathrm{Stn} .201)$, lowest $\delta^{15} \mathrm{~N}(\mathrm{Stn} . \mathrm{T}-31)$, or highest C/N (Stns. 201 and 210) (Figs. 5 to 7 , Table 1). The fractions estimated by $\delta^{13} \mathrm{C},{ }^{15} \mathrm{~N}$ and C/N were 54, 52 and $45 \%$, respectively. Therefore about half of the organic matter in the sediment deposited near the mouth of the Tokachi River was probably of terrestrial origin.

\subsection{Mechanisms regulating distribution of sedimentary organic matter off Tokachi}


In continental margin sediments, maximum organic $\mathrm{C}$ contents have been often observed near river mouth and in the upper slope (Tyson, 1995; de Haas et al., 2002; Kao et al., 2003). Organic C content is generally well correlated with silt plus clay content in the sediments above $2000 \mathrm{~m}$ water depth (Tyson, 1995). Our results also showed such trends (Figs. 3 and 4). The correlation between $\mathrm{C}$ and silt plus clay has been attributed to the accumulation of organic matter in fine sediment fraction, because of the sorption of organic matter onto mineral surfaces and its subsequent protection against microbial degradation and/or the similarity of the settling velocity between fine mineral grains and discrete organic particles (Hedges and Keil, 1995; Tyson, 1995). Currents and waves inhibit sedimentation of fine particles on the shallow shelf, which often results in low silt plus clay content in the sediment except near the river mouth where fine sediment is continuously supplied (Tyson, 1995; de Haas et al., 2002).

The contents of organic C, total $\mathrm{N}$ and silt plus clay at Stn. $108(908 \mathrm{~m})$ and at Stn. $188(1076 \mathrm{~m})$ were lower than at other stations located at water depth around 1000 m (Figs. 3 and 4). However, the slope of the sea floor at Stn. 108 is relatively steep compared to the other stations and Stn. 188 is located on the ridge of a spur. Such topography presumably inhibits the sedimentation of organic-rich fine-sediment.

Organic C content in the sediment off Tokachi was well correlated with silt plus clay content, but with different regression lines for the stations shallower and deeper than $134 \mathrm{~m}$ water depth (Fig. 9). The slope of the regression line of shallower stations is steeper than that of deeper ones due to several stations with higher organic C / (silt + clay), which were located around the mouth of the Tokachi River (Stns. 189, 201, 210, 219 and 220) and in the western end of the shelf (Stns. 236 and 244) (Fig. 4). These results suggest that organic $\mathrm{C}$ content in the sediment off Tokachi was controlled mostly by the 
above-mentioned processes, but other factors also play a role.

The ratio of organic C / (silt + clay) in continental margin sediments is generally higher in the areas of high productivity with low oxygen bottom water than in others, which has been explained by the suppression of biological degradation under anaerobic conditions (Hedges and Keil, 1995). However, this explanation cannot apply to the shelf sediment off Tokachi under oxic bottom water (Kudo, pers. comm.). If the finer particle content in the silt plus clay fraction at the above-mentioned stations was higher than others, organic C / (silt + clay) can be elevated because of the larger surface area. Organic $\mathrm{C} /($ silt + clay) was correlated with (clay content: $<3.9 \mu \mathrm{m})$ per (silt plus clay content) at the stations of $\geq 134 \mathrm{~m}$ water depth (Fig. 10a). At the shallower stations, however, such correlation was not observed $(p>0.05)$ and clay / (silt + clay) was not higher than at deeper stations.

The stations of high organic C / (silt + clay) ratio were generally located on the inner shelf where terrestrial organic matter was supplied (Fig. 4). Although organic C / (silt + clay) tends to be elevated at stations with low $\delta^{13} \mathrm{C}$, these parameters were not well correlated to each other (Fig. 10b). However, the correlation between organic C / (silt + clay) and $\mathrm{C} / \mathrm{N}$ was relatively high (Fig. 10c), suggesting that a fraction of terrestrial organic matter having a higher $\mathrm{C} / \mathrm{N}$ ratio served to elevate organic $\mathrm{C} /($ silt + clay) at the shallower stations. Volkman et al. (2000) reported higher organic C / (silt + clay) in some sections of a sediment core from the tidal flat in the German Wadden Sea compared to the TOC-grain size relationship obtained by other sections. They attributed it to the inclusion of eroded peat in these layers. Deposition of discrete organic particles derived from terrestrial vascular plants might result in an elevated ratio in the shallow sediments off Tokachi. Thus, it is likely that the differences of the origin and the nature of organic matter are additional factors affecting the distribution of organic $\mathrm{C}$ content in the 
sediment off Tokachi.

\section{Summary and conclusions}

Comparison of $\delta^{13} \mathrm{C}, \delta^{15} \mathrm{~N}$ and $\mathrm{C} / \mathrm{N}$ values in riverine suspended POM with estuarine sediment of the Tokachi River revealed that POM transport during the spring snowmelt was likely an important process for the supply of terrestrial organic particles to the coastal waters. The changes in $\delta^{13} \mathrm{C}$ and $\delta^{15} \mathrm{~N}$ of surface-suspended POM off Tokachi observed in May, August and November probably reflected seasonal changes in phytoplankton growth rate and nitrate availability.

Based on spatial patterns of $\delta^{13} \mathrm{C}, \delta^{15} \mathrm{~N}$ and $\mathrm{C} / \mathrm{N}$ values in surface sediments off Tokachi, and the relationship of these values between the sediment and terrestrial and marine end members (estimated from Tokachi River and seawater data), we conclude that about half of the organic matter in the sediment was of terrestrial origin near the mouth of the Tokachi River and the sedimentary organic matter from 134 to $1995 \mathrm{~m}$ water depth was of marine origin.

Organic $\mathrm{C}$ and total $\mathrm{N}$ contents in the surface sediment off Tokachi were high near the Tokachi River mouth on the inner shelf and at around $1000 \mathrm{~m}$ on the slope. Organic C content was well correlated with silt plus clay content, but with different regression lines for those stations shallower and deeper than $134 \mathrm{~m}$. The slope of the regression line for the shallower stations was steeper than for deeper ones due to the several stations of higher $\mathrm{C}$ content with the elevated $\mathrm{C} / \mathrm{N}$ ratio. Transport and deposition of organic-rich fine-grained particles by hydrodynamic processes are major factors controlling the distribution of sedimentary organic matter off Tokachi. In addition, the supply of a fraction of terrestrial organic matter with high $\mathrm{C} / \mathrm{N}$ probably also contributed 
to increase organic $\mathrm{C}$ content on the inner shelf.

\section{Acknowledgements}

We are grateful to the captain, crew and scientists on the cruises of R/V Hakurei-maru No.2 and T/S Ushio-maru for their generous assistance at the samplings. The research on the cruise of R/V Hakurei-maru No.2 was a part of the "Marine geological mapping project of the continental shelves around Japan" program supported by the Geological Survey of Japan/AIST. We thank T. Irino, G. Ono, O. Seki, Y. Adachi and K. Horikawa for assisting the research in the Tokachi River and off Tokachi. We also thank I. Koike, T. Miyajima and Y. Umezawa for the use of DELTA plus XP mass spectrometer. We acknowledge the Japan Oceanographic Data Center, Japan Meteorological Agency, and the River Bureau, Ministry of Land, Infrastructure and Transport, Japan, for use of the data on water temperature off Tokachi, precipitation in the Tokachi plains, and the flow of the Tokachi River, respectively. This study was partly funded by the 21st-Century Center of Excellence Program (E-01) of Ministry of Education, Culture, Sports, Science and Technology (MEXT), the Grant-in-Aid for Science Research, No. 16201001, No. 15310002 and No. 15310019 of MEXT, and the Grant-in-Aid for Young Scientists (A) of MEXT to KS (No.15681001). 


\section{References}

Altabet, M.A., 1988. Variations in nitrogen isotopic composition between sinking and suspended particles - implications for nitrogen cycling and particle transformation in the open ocean. Deep-Sea Res., 35: 535-554.

Altabet, M.A., 1989. A time-series study of the vertical structure of nitrogen and particle dynamics in the Sargasso Sea. Limnol. Oceanogr., 34: 1185-1201.

Altabet, M.A., Robinson, A.R. and Walstad, L.J., 1986. A model for the vertical flux of nitrogen in the upper ocean: Stimulating the alternation of isotope ratios. J. Mar. Res., 44: 203-225.

Altabet, M.A., Deuser, W.G., Honjo, S. and Stienen, C., 1991. Seasonal and depth-related changes in the source of sinking particles in the North Atlantic. Nature, 354: 136-139.

Altabet, M.A. and Francois, R., 1994. The use of nitrogen isotopic ratio for reconstruction of past changes in surface ocean nutrient utilization. In: Zahn, R., Kaminski, M., Labeyrie, L., Pedersen, T.F. (Eds.), Carbon cycling in the glacial ocean: constraints on the ocean's role in global change: quantitative approaches in paleoceanography. Springer, pp. 281-306.

Altabet, M.A., Pilskaln, C., Thunell, R., Pride, C., Sigman, D., Chavez, F., and Francois, R., 1999. The nitrogen isotope biogeochemistry of sinking particles from the margin of the Eastern North Pacific. Deep-Sea Res. I, 46: 655-679.

Benner, R., Fogel, M.L., Sprague, E.K. and Hodson, R.E., 1987. Depletion of ${ }^{13} \mathrm{C}$ in lignin and its implications for stable carbon isotope studies. Nature, 329: 708-710.

Benner, R., Fogel, M.L. and Sprague, E.K., 1991. Diagenesis of belowground biomass of Spartina alterniflora in salt-marsh sediments. Limnol. Oceanogr., 36: 1358-1374.

Bird, M.I., Brunskill, G.J. and Chivas, A.R., 1995. Carbon-isotope composition of sediments from the Gulf of Papua. Geo-Mar. Lett., 15: 153-159.

Cifuentes, L.A., Sharp, J.H. and Fogel, M.L., 1988. Stable carbon and nitrogen isotope biogeochemistry in the Delaware estuary. Limnol. Oceanogr., 33: 1102-1115.

Cloern, J.E., Canuel, E.A. and Harris, D., 2002. Stable carbon and nitrogen isotope composition of aquatic and terrestrial plants of the San Francisco Bay estuarine system. Limnol. Oceanogr., 47: 713-729.

de Haas, H., van Weering, T.C.E. and de Stieger, H., 2002. Organic carbon in shelf seas: sinks or sources, processes and products. Continental Shelf Res., 22: 691-717.

Eadie, B.J. and Jeffrey, L.M., 1973. $\delta^{13} \mathrm{C}$ analyses of oceanic particulate organic matter. Marine Chemistry, 1: 199-209.

Fry, B. and Sherr, E.B., 1984. $\delta^{13} \mathrm{C}$ measurements as indicators of carbon flow in marine and freshwater ecosystems. Contrib. Mar. Sci., 27: 13-47. 
Geider, R.J., 1987. Light and temperature dependence of the carbon to chlorophyll a ratio in microalgae and cyanobacteria: implications for physiology and growth of phytoplankton. New Phytol., 106: 1-34.

Goericke, R. and Fry, B., 1994. Variations of marine plankton $\delta^{13} \mathrm{C}$ with latitude, temperature, and dissolved $\mathrm{CO}_{2}$ in the world ocean. Global Biogeochem. Cycles, 8: 85-90.

Goñi, M.A., Teixeira, M.J. and Perkey, D.W., 2003. Sources and distribution of organic matter in a river-dominated estuary (Winyah Bay, SC, USA). Estuar. Coast. Shelf Sci., 57: 1023-1048.

Gordon, E.S. and Goñi, M.A., 2003. Sources and distribution of terrigenous organic matter delivered by the Atchafalaya River to sediments in the northern Gulf of Mexico. Geochim. Cosmochim. Acta, 67: 2359-2375.

Hedges, J. I. and Parker, P. L., 1976. Land-derived organic matter in surface sediments from the Gulf of Mexico. Geochim. Cosmochim. Acta, 40: 1019-1029.

Hedges, J.I. and Keil, R.G., 1995. Sedimentary organic matter preservation: an assessment and speculative synthesis. Mar. Chem., 49: 81-115.

Hein, T., Baranyi, C., Herndl, G.J., Wanek, W. and Schiemer, F., 2003. Allochthonous and autochthonous particulate organic matter in floodplains of the River Danube: the importance of hydrological connectivity. Freshwater Biol., 48: 220-232.

Kao, S.J., Lin, F.J. and Liu, K.K., 2003. Organic carbon and nitrogen contents and their isotopic compositions in surficial sediments from the East China Sea shelf and the southern Okinawa Trough. Deep-Sea Res. II, 50: 1203-1217.

Kasai, H., Saito, H., Yoshimori, A. and Taguchi S., 1997. Variability in timing and magnitude of spring bloom in the Oyashio region, the western subarctic Pacific off Hokkaido, Japan. Fish. Oceanogr., 6: 118-129.

Kasai, H., Saito, H., Kashiwai, M., Taneda, T., Kusaka, A., Kawasaki, Y., Kono, T., Taguchi, S. and Tsuda, A., 2001. Seasonal and interannual variations in nutrients and plankton in the Oyashio region: A summary of a 10-years observation along the A-line. Bull. Hokkaido Natl. Fish. Res. Inst., 65: 55-134.

Kawai, H., 1972. Hydrography of the Kuroshio Extension. In: Stommel, H., Yoshida, K., (Eds), Kuroshio. University of Tokyo Press, Tokyo, pp. 235-352.

Kendall. C., Silva, S.R., and Kelly, V.J., 2001. Carbon and nitrogen isotopic compositions of particulate organic matter in four large river systems across the United States. Hydrol. Process., 15: 1301-1346.

Krumbein, W.C. and Pettijohn, F.J., 1938. Manual of Sedimentary Petrography, Appleton-Century-Crofts, Inc., New York.

Laws, E.A., Popp, B.N., Bidigare, R.R., Kennicutt, M.C. and Macko, S.A., 1995. Dependence of phytoplankton carbon isotopic composition on growth rate and 
$\left[\mathrm{CO}_{2}\right]_{\mathrm{aq}}$ : Theoretical considerations and experimental results. Geochim. Cosmochim. Acta, 59: 1131-1138.

Lehmann, M.F., Bernasconi, S.M., Barbieri, A. and McKenzie, J.A., 2002. Preservation of organic matter and alteration of its carbon and nitrogen isotope composition during simulated and in situ early diagenesis. Geochim. Cosmochim. Acta, 66: 3573-3584.

Limsakul, A., Saino, T., Goes, J.I. and Midorikawa, T., 2002. Seasonal variability in the lower trophic level environments of the western subtropical Pacific and Oyashio Waters - a retrospective study. Deep Sea Res. II, 49: 5487-5512.

Lourey, M.J., Trull, T.W. and Sigman, D.M., 2003. Sensitivity of $\delta^{15} \mathrm{~N}$ of nitrate, surface suspended and deep sinking particulate nitrogen to seasonal nitrate depletion in the Southern Ocean. Global Biogeochem. Cycles, 17: Art. No. 1081.

Lourey, M.J., Trull, T.W. and Tilbrook, B., 2004. Sensitivity of $\delta^{13} \mathrm{C}$ of Southern Ocean suspended and sinking organic matter to temperature, nutrient utilization, and atmospheric $\mathrm{CO}_{2}$. Deep-Sea Res. I, 51: 281-305.

Meybeck, M., 1982. Carbon, nitrogen, and phosphorus transport by world rivers. Am. J. Sci., 282: 401-450.

Michener, R.H. and Schell, D.M., 1994. Stable isotope ratios as tracers in marine aquatic food webs. In: Lajtha, K., Michener, R.H. (Eds.), Stable isotopes in ecology and environmental science. Blackwell Scientific Publications, pp. 138-157.

Middelburg, J.J. and Nieuwenhuize, J., 1998. Carbon and nitrogen stable isotopes in suspended matter and sediments from the Schelde Estuary. Mar. Chem., 60: 217-225.

Minagawa, M., Ohashi, M., Kuramoto, T. and Noda, N., 2001. $\delta^{15} \mathrm{~N}$ of PON and nitrate as a clue to the origin and transformation of nitrogen in the subarctic North Pacific and its marginal sea. J. Oceanogr., 57: 285-300.

Mino, Y., Saino, T., Suzuki, K. and Maranon, E., 2002. Isotopic composition of suspended particulate nitrogen $\left(\delta^{15} \mathrm{~N}_{\text {sus }}\right)$ in surface waters of the Atlantic Ocean from $50^{\circ} \mathrm{N}$ to 50 S. Global Biogeochem. Cycles, 16: Art. No. 1059.

Montoya, J.P., 1994. Nitrogen isotope fractionation in the modern ocean: implications for the sedimentary record. In: Zahn, R., Kaminski, M., Labeyrie, L., Pedersen, T. F. (Eds.), Carbon cycling in the glacial ocean: constraints on the ocean's role in global change: quantitative approaches in paleoceanography. Springer, pp. 259-279.

Mook, W.G. and Tan, T.C., 1991. Stable carbon isotopes in rivers and estuaries. In: Degens, E.T., Kempe, S., Richey, J.E. (Eds.), Biogeochemistry of major world rivers. SCOPE 42, John Wiley \& Sons, pp. 245-264.

Naidu, A. S., Cooper, L. W., Finney, B. P., Macdonald, R. W., Alexander, C. and Semiletov, I. P., 2000. Organic carbon isotope ratios $\left(\delta^{13} \mathrm{C}\right)$ of Arctic Amerasian Continental 
shelf sediments. Int. J. Earth Sciences, 89: 522-532.

Nakanishi, T, and Minagawa, M., 2003. Stable carbon and nitrogen isotopic compositions of sinking particles in the northeast Japan Sea. Geochemical J., 37: 261-275.

Nakatsuka, T., Handa, N., Wada, E. and Wong, C. S., 1992. The dynamic changes of stable isotopic ratios of carbon and nitrogen in suspended and sedimented particulate organic matter during a phytoplankton bloom. J. Mar. Res., 50: 267-296.

Nakatsuka, T., Handa, N., Harada, N., Sugimoto, T. and Imaizumi, S., 1997. Origin and decomposition of sinking particulate organic matter in the deep water column inferred from the vertical distributions of its $\delta^{15} \mathrm{~N}, \delta^{13} \mathrm{C}$ and $\delta^{14} \mathrm{C}$. Deep-Sea Res. I, 44: 1957-1979.

Ogawa, N. and Ogura, N., 1997. Dynamics of particulate organic matter in the Tamagawa Estuary and Inner Tokyo Bay. Estuar. Coast. Shelf Sci., 44: 263-273.

Ohashi, M., 1999. The origin of nitrogen in the marginal sea using stable isotope analysis. Master Thesis, Graduate School of Environmental Earth Science, Hokkaido University, Japan, unpublished (in Japanese).

Ohtani, K., 1971. Studies on the changes of the hydrographic conditions in the Funka Bay II. Characteristics of the waters occupying the Funka Bay. Bull. Fac. Fish. Hokkaido Univ., 22: 58-66 (in Japanese with English abstract).

Ohtani, K., 1991. To confirm again the characteristics of the Oyashio. Bull. Hokkaido Natl. Fish. Res. Inst., 55: 1-24 (in Japanese with English abstract).

Parsons, T. R., Maita, Y. and Lalli, C.M., 1984. A Manual of Chemical and Biological Methods for Seawater Analysis. Pergamon Press, Oxford.

Peters, K.E., Sweeney, R.E. and Kaplan, I.R., 1978. Correlation of carbon and nitrogen stable isotope ratios in sedimentary organic matter. Limnol. Oceanogr., 23: 598-604.

Rau, G.H., 1994. Variations in sedimentary organic $\delta^{13} \mathrm{C}$ as a proxy for past changes in ocean and atmospheric $\mathrm{CO}_{2}$ concentrations. In: Zahn, R., Kaminski, M., Labeyrie, L., Pedersen, T.F. (Eds.), Carbon cycling in the glacial ocean: constraints on the ocean's role in global change: quantitative approaches in paleoceanography. Springer, pp. 307-321.

Rau, G.H., Sweeney, R.E. and Kaplan, I.R., 1982. Plankton ${ }^{13} \mathrm{C}:{ }^{12} \mathrm{C}$ ratio changes with latitude: Differences between northern and southern oceans. Deep-Sea Res., 29: 1035-1039.

Rau, G.H., Low, C., Pennington, J.T., Buck, K.R. and Chavez, F.P., 1998. Suspended particulate nitrogen $\delta^{15} \mathrm{~N}$ versus nitrate utilization: observations in Monterey Bay, CA. Deep Sea Res. II, 45: 1603-1616.

Rau, G.H., Chavez, F.P. and Friederich, G.E., 2001. Plankton ${ }^{13} \mathrm{C} /{ }^{12} \mathrm{C}$ variations in 
Monterey Bay, California: evidence of non-diffusive inorganic carbon uptake by phytoplankton in an upwelling environment. Deep-Sea Res. I, 48: 79-94.

Saino, T., 1992. ${ }^{15} \mathrm{~N}$ and ${ }^{13} \mathrm{C}$ natural abundance in suspended particulate organic matter from a Kuroshio warm-core ring. Deep-Sea Res., 39, S347-S362.

Saino, T. and Hattori, A., 1980. ${ }^{15} \mathrm{~N}$ natural abundance in oceanic suspended particulate matter. Nature, 283: 752-754.

Saino, T. and Hattori, A., 1985. Variation of ${ }^{15} \mathrm{~N}$ natural abundance of suspended organic matter in shallow oceanic waters. In: Sigleo, A.C., Hattori, A. (Eds.), Marine and estuarine geochemistry, Lewis Publisher, pp. 1-13.

Saino, T. and Hattori, A., 1987. Geographical variation of the water column distribution of suspended particulate organic nitrogen and its ${ }^{15} \mathrm{~N}$ natural abundance in the Pacific and its marginal seas. Deep-Sea Res., 34: 807-827.

Saito, H., Kasai, H., Kashiwai, M., Kawasaki, Y., Kono, T., Taguchi, S. and Tsuda, A., 1998. General description of seasonal variations in nutrients, chlorophyll a, and netplankton biomass at $A$-line transect, western subarctic Pacific, from 1990 to 1994 . Bull. Hokkaido Natl. Fish. Res. Inst., 62: 1-62.

Schneider, B., Schlitzer, R., Fischer, G, and Nothig, E.M., 2003. Depth-dependent elemental compositions of particulate organic matter (POM) in the ocean. Global Biogeochem. Cycles, 17: Art. No. 1032.

Strickland, J. D. H. and Parsons, T. R., 1972. A Practical Handbook of Seawater Analysis. Fisheries Research Board of Canada Bulletin 167.

Suess, E., 1980. Particulate organic carbon flux in the Oceans: Surface productivity and oxygen utilization. Nature, 288: 260-263.

Suzuki, R. M. and Ishimaru, T., 1990. An improved method for the determination of phytoplankton chlorophyll using N,N-dimethylformamide, J. Oceanogr. Soc. Japan, 46: 190-194.

Suzuki, K., Hinuma, A., Saito, H., Kiyosawa, H., Liu, H., Saino, T. and Tsuda, A., 2005. Responses of phytoplankton and heterotrophic bacteria in the northwest subarctic Pacific to in situ iron fertilization as estimated by HPLC pigment analysis and flow cytometry. Prog. Oceanogr. 64,167-187.

Taira, Y., 2004. Loading structure of terrestrial organic matter and microbial carbon circulation in the Tokachi River estuary. Master Thesis, Graduate School of Fisheries Science, Hokkaido University, Japan, unpublished.

Takahashi, K., Wada, E. and Sakamoto, M., 1991. Relationship between carbon isotope discrimination and the specific growth rate of green algae Chlamydomonas reinhardtii. Jpn. J. Limnol., 52: 105-112.

Thompson, P.A., Guo, M.-X. and Harrison, P.J., 1992. Effects of variation in temperature. I. On the biochemical composition of eight species of marine phytoplankton. J. 
Phycol., 28: 481-488.

Thornton, S.F. and McManus, J., 1994. Application of organic carbon and nitrogen stable isotope and $\mathrm{C} / \mathrm{N}$ ratios as source indicators of organic matter provenance in estuarine systems: evidence from the Tay Estuary, Scotland. Estuar. Coast. Shelf Sci., 38: 219-233.

Tyson, R.V., 1995. Sedimentary Organic Matter. Chapman \& Hall, London.

Volkman, J.K., Rohjans, D., Rullkötter, J., Scholz-Böttcher, B.M. and Liebezeit, G., 2000. Sources and diagenesis of organic matter in tidal flat sediments from the German Wadden Sea. Continental Shelf Res. 20: 1139-1158.

Voss, M., Altabet, M.A. and Bodungen, B.v., 1996. $\delta^{15} \mathrm{~N}$ in sedimenting particles as indicator of euphotic-zone processes. Deep Sea Res. I, 43: 33-47.

Wada, E., Minagawa, M., Mizutani, H., Tsuji, T., Imaizumi, R. and Karasawa, K., 1987. Biogeochemical studies on the transport of organic matter along the Otsuchi River watershed, Japan. Estuar. Coast. Shelf Sci., 25: 321-336.

Wollast, R., 1998. Evaluation and comparison of the global carbon cycle in the coastal zone and in the open ocean. In: Robinson, A.R., Brink, K.H. (Eds.), The Sea, v. 11, The global coastal ocean: regional studies and syntheses. Wiley, pp. 213-252.

Wu, J., Calvert, S.E., Wong, C.S. and Whitney, F.A., 1999. Carbon and nitrogen isotopic composition of sedimenting particulate material at Station Papa in the subarctic northeast Pacific. Deep Sea Res. II, 46, 2793-2832. 


\section{Figure captions}

Fig. 1. Sampling locations of river water (Stn. Moiwa: $\mathbf{\nabla}$ ), estuarine water and sediment (Stn. Kako-1, Kako-2 and Kako-3: $\Delta$ ), seawater (Stn. T-35: ०), and shelf and slope sediments collected during the cruises of R/V Hakurei-maru No. $2(\diamond)$ and of T/S Ushio-maru $(\diamond)$.

Fig. 2. Vertical distributions of density $(\sigma \theta)$, nitrate plus nitrite, chlorophyll a (Chl.a), suspended POC, suspended PN, C/N, $\delta^{13} \mathrm{C}-\mathrm{POC}, \delta^{15} \mathrm{~N}-\mathrm{PN}$ and POC/chlorophyll $a$ at Stn. T-35 off Tokachi. $\quad$, May; $\times$, August; $\Delta$, November. Note the difference on the ordinate between 0-100 $\mathrm{m}$ and 100-500 $\mathrm{m}$ water depth.

Fig. 3. Horizontal distribution of organic $\mathrm{C}$ contents in the surface sediments off Tokachi (left panel) and its change with water depth (right panel).

Fig. 4. As Fig. 3, but silt plus clay content in the sediment.

Fig. 5. As Fig. 3, but $\delta^{13} \mathrm{C}$ of organic $\mathrm{C}$ in the sediment. An arrow indicates the station exhibiting the lowest $\delta^{13} \mathrm{C}$.

Fig. 6. As Fig. 3, but $\delta^{15} \mathrm{~N}$ of total $\mathrm{N}$ in the sediment. An arrow indicates the station exhibiting the lowest $\delta^{15} \mathrm{~N}$.

Fig. 7. As Fig. 3, but $\mathrm{C} / \mathrm{N}$ ratio in the sediment. Arrows indicate two stations exhibiting the highest $\mathrm{C} / \mathrm{N}$. 
Fig. 8. The $\delta^{13} \mathrm{C}-\delta^{15} \mathrm{~N}$ plot (a) and $\delta^{13} \mathrm{C}-\mathrm{C} / \mathrm{N}$ plot (b) of all samples obtained in this study. The rectangle of dashed line in Fig. 8a represents the estimated range of marine organic matter (see section 4.5). The arrow on the abscissa in Fig. 8b indicates $\mathrm{C} / \mathrm{N}$ ratio in suspended particles at Stn. Moiwa in April.

Fig. 9. The relationship between organic $\mathrm{C}$ content and silt plus clay content in the surface sediment off Tokachi. Open and closed circles represent the values at stations with a water depth of $<134 \mathrm{~m}$ and $\geq 134 \mathrm{~m}$, respectively.

Fig. 10. The plot of organic C content / (silt + clay content) against clay content / (silt + clay content) (a), $\delta^{13} \mathrm{C}(\mathrm{b})$ and $\mathrm{C} / \mathrm{N}(\mathrm{c})$ in the surface sediment off Tokachi. Open and closed circles represent the values at stations with a water depth of $<134 \mathrm{~m}$ and $\geq 134 \mathrm{~m}$, respectively. 
Table 1. Locations of the sampling site, organic $\mathrm{C}$ and total $\mathrm{N}$ contents, their isotopic compositions, and silt plus clay content in the surface sediment off Tokachi.

$\begin{array}{lllllllll}\text { Stn. }^{a} & \text { Latitude Longitude } & \begin{array}{l}\text { Water } \\ \text { depth }\end{array} & \text { Org. } \mathrm{C}^{\mathrm{b}} & \mathrm{TN}^{\mathrm{b}} & \mathrm{C} / \mathrm{N} & \delta^{13} \mathrm{C} & \delta^{15} \mathrm{~N} & \begin{array}{l}\text { Silt }+ \\ \text { Clay }\end{array}\end{array}$

\begin{tabular}{|c|c|c|c|c|c|c|c|c|c|}
\hline & $\left({ }^{\circ} \mathrm{N}\right)$ & $\left({ }^{\circ} \mathrm{E}\right)$ & (m) & (weight \%) & (weight \%) & $\left(\mathrm{mol} \mathrm{mol}^{-1}\right)$ & (\%орDB $)$ & $\left(\%_{\mathrm{AIR}}\right)$ & (weight \%) \\
\hline T-21 & $42^{\circ} 35.50^{\prime}$ & $143^{\circ} 37.50^{\prime}$ & 23 & 1.10 & 0.124 & 10.3 & -23.5 & 4.3 & $-^{\mathrm{C}}$ \\
\hline T-24 & $42^{\circ} 27.00^{\prime}$ & $143^{\circ} 49.50^{\prime}$ & 158 & 0.26 & 0.039 & 7.8 & -21.2 & 5.6 & $-{ }^{c}$ \\
\hline T-31 & $42^{\circ} 39.00^{\prime}$ & $143^{\circ} 40.50^{\prime}$ & 21 & 0.34 & 0.040 & 9.3 & -23.6 & 4.0 & $-^{c}$ \\
\hline T-32 & $42^{\circ} 37.00^{\prime}$ & $143^{\circ} 44.00^{\prime}$ & 37 & 0.46 & 0.054 & 9.8 & -23.0 & 4.9 & $-{ }^{c}$ \\
\hline T-33 & $42^{\circ} 33.50^{\prime}$ & $143^{\circ} 49.00^{\prime}$ & 85 & 0.42 & 0.059 & 8.4 & -21.2 & 5.6 & $-{ }^{c}$ \\
\hline T-34 & $42^{\circ} 30.00^{\prime}$ & $143^{\circ} 54.50^{\prime}$ & 254 & 0.47 & 0.065 & 8.3 & -21.0 & 5.0 & - $^{c}$ \\
\hline T-43 & $42^{\circ} 37.50^{\prime}$ & $143^{\circ} 54.00^{\prime}$ & 89 & 0.53 & 0.066 & 9.4 & -21.2 & 5.9 & $-^{c}$ \\
\hline 101 & $42^{\circ} 29.80^{\prime}$ & $144^{\circ} 36.58^{\prime}$ & 1868 & 1.06 & 0.144 & 8.6 & -21.2 & 6.0 & 58.8 \\
\hline 108 & $42^{\circ} 36.04^{\prime}$ & $144^{\circ} 28.00^{\prime}$ & 908 & 0.53 & 0.074 & 8.3 & -21.0 & 6.3 & 22.4 \\
\hline 110 & $42^{\circ} 27.98^{\prime}$ & $144^{\circ} 31.98^{\prime}$ & 1445 & 1.44 & 0.196 & 8.6 & -20.9 & 6.0 & 64.8 \\
\hline 111 & $42^{\circ} 23.00^{\prime}$ & $144^{\circ} 36.03^{\prime}$ & 1575 & 1.18 & 0.159 & 8.6 & -21.2 & 5.8 & 79.2 \\
\hline 112 & $42^{\circ} 17.97^{\prime}$ & $144^{\circ} 40.01^{\prime}$ & 1784 & 0.78 & 0.110 & 8.3 & -21.2 & 6.1 & 49.3 \\
\hline 113 & $42^{\circ} 12.98^{\prime}$ & $144^{\circ} 43.99^{\prime}$ & 1995 & 1.02 & 0.144 & 8.3 & -21.2 & 5.5 & 64.9 \\
\hline 118 & $42^{\circ} 35.30^{\prime}$ & $144^{\circ} 24.68^{\prime}$ & 1280 & 1.61 & 0.228 & 8.2 & -21.0 & 5.8 & 83.2 \\
\hline 119 & $42^{\circ} 32.01^{\prime}$ & $144^{\circ} 23.99^{\prime}$ & 1057 & 1.80 & 0.240 & 8.8 & -21.0 & 6.2 & 80.2 \\
\hline 120 & $42^{\circ} 28.00^{\prime}$ & $144^{\circ} 25.98^{\prime}$ & 1124 & 1.87 & 0.257 & 8.5 & -20.8 & 5.8 & 86.4 \\
\hline 121 & $42^{\circ} 24.03^{\prime}$ & $144^{\circ} 28.01^{\prime}$ & 1399 & 1.45 & 0.195 & 8.7 & -21.1 & 5.8 & 82.8 \\
\hline 122 & $42^{\circ} 19.03^{\prime}$ & $144^{\circ} 32.01^{\prime}$ & 1622 & 1.56 & 0.219 & 8.3 & -21.1 & 5.7 & 87.0 \\
\hline 123 & $42^{\circ} 14.00^{\prime}$ & $144^{\circ} 34.01^{\prime}$ & 1757 & 1.17 & 0.169 & 8.1 & -21.1 & 5.5 & 71.9 \\
\hline 124 & $42^{\circ} 09.09^{\prime}$ & $144^{\circ} 40.03^{\prime}$ & 1852 & 1.01 & 0.144 & 8.2 & -21.1 & 5.8 & 67.9 \\
\hline 125 & $42^{\circ} 04.04^{\prime}$ & $144^{\circ} 44.04^{\prime}$ & 1970 & 0.73 & 0.100 & 8.5 & -21.0 & 5.7 & 56.5 \\
\hline 130 & $42^{\circ} 35.99^{\prime}$ & $144^{\circ} 15.95^{\prime}$ & 756 & 0.74 & 0.100 & 8.7 & -21.0 & 5.5 & 39.5 \\
\hline 131 & $42^{\circ} 32.00^{\prime}$ & $144^{\circ} 18.01^{\prime}$ & 935 & 1.21 & 0.161 & 8.7 & -21.1 & 6.0 & 61.6 \\
\hline 132 & $42^{\circ} 28.00^{\prime}$ & $144^{\circ} 19.98^{\prime}$ & 1042 & 2.05 & 0.276 & 8.7 & -21.1 & 5.5 & 92.0 \\
\hline 133 & $42^{\circ} 23.99^{\prime}$ & $144^{\circ} 22.01^{\prime}$ & 1251 & 1.85 & 0.257 & 8.4 & -21.0 & 6.0 & 83.0 \\
\hline 134 & $42^{\circ} 20.03^{\prime}$ & $144^{\circ} 24.02^{\prime}$ & 1434 & 1.55 & 0.219 & 8.2 & -20.9 & 6.2 & 87.6 \\
\hline 135 & $42^{\circ} 15.00^{\prime}$ & $144^{\circ} 28.03^{\prime}$ & 1558 & 1.52 & 0.218 & 8.1 & -20.8 & 5.9 & 92.0 \\
\hline 136 & $42^{\circ} 10.02^{\prime}$ & $144^{\circ} 31.97^{\prime}$ & 1633 & 1.10 & 0.156 & 8.2 & -20.9 & 5.6 & 79.6 \\
\hline 137 & $42^{\circ} 05.01^{\prime}$ & $144^{\circ} 36.00^{\prime}$ & 1699 & 0.67 & 0.094 & 8.4 & -21.2 & 5.3 & 59.7 \\
\hline 143 & $42^{\circ} 35.99^{\prime}$ & $144^{\circ} 09.96^{\prime}$ & 664 & 1.02 & 0.142 & 8.4 & -20.6 & 6.2 & 50.5 \\
\hline 144 & $42^{\circ} 31.98^{\prime}$ & $144^{\circ} 15.00^{\prime}$ & 792 & 1.22 & 0.162 & 8.8 & -21.3 & 5.8 & 46.4 \\
\hline 145 & $42^{\circ} 28.00^{\prime}$ & $144^{\circ} 14.03^{\prime}$ & 941 & 1.40 & 0.192 & 8.5 & -21.0 & 6.5 & 74.2 \\
\hline 146 & $42^{\circ} 23.97^{\prime}$ & $144^{\circ} 15.96^{\prime}$ & 1118 & 2.33 & 0.316 & 8.6 & -21.1 & 5.8 & 86.8 \\
\hline 147 & $42^{\circ} 20.00^{\prime}$ & $144^{\circ} 18.05^{\prime}$ & 1288 & 1.87 & 0.256 & 8.5 & -21.1 & 5.4 & 85.8 \\
\hline 148 & $42^{\circ} 16.09^{\prime}$ & $144^{\circ} 20.15^{\prime}$ & 1380 & 1.78 & 0.250 & 8.3 & -20.9 & 5.7 & 93.0 \\
\hline 149 & $42^{\circ} 11.01^{\prime}$ & $144^{\circ} 24.11^{\prime}$ & 1491 & 1.40 & 0.195 & 8.4 & -20.9 & 5.7 & 81.3 \\
\hline 150 & $42^{\circ} 05.99^{\prime}$ & $144^{\circ} 27.99^{\prime}$ & 1548 & 0.99 & 0.143 & 8.0 & -20.9 & 6.6 & 73.9 \\
\hline 151 & $42^{\circ} 01.00^{\prime}$ & $144^{\circ} 31.99^{\prime}$ & 1706 & 0.95 & 0.129 & 8.6 & -21.0 & 5.3 & 77.1 \\
\hline 155 & $42^{\circ} 39.92^{\prime}$ & $144^{\circ} 02.00^{\prime}$ & 134 & 0.34 & 0.048 & 8.3 & -21.2 & 5.9 & 16.4 \\
\hline 156 & $42^{\circ} 36.00^{\prime}$ & $144^{\circ} 04.03^{\prime}$ & 531 & 1.33 & 0.183 & 8.5 & -21.1 & 6.1 & 72.6 \\
\hline 157 & $42^{\circ} 31.99^{\prime}$ & $144^{\circ} 05.99^{\prime}$ & 678 & 1.39 & 0.195 & 8.3 & -20.9 & 6.0 & 66.1 \\
\hline 158 & $42^{\circ} 28.00^{\prime}$ & $144^{\circ} 08.01^{\prime}$ & 916 & 1.74 & 0.231 & 8.8 & -21.0 & 6.0 & 87.4 \\
\hline 159 & $42^{\circ} 23.90^{\prime}$ & $144^{\circ} 09.98^{\prime}$ & 948 & 1.82 & 0.248 & 8.6 & -21.1 & 5.9 & 87.6 \\
\hline 160 & $42^{\circ} 19.98^{\prime}$ & $144^{\circ} 11.98^{\prime}$ & 1073 & 1.69 & 0.242 & 8.1 & -20.8 & 6.1 & 77.3 \\
\hline 161 & $42^{\circ} 16.06^{\prime}$ & $144^{\circ} 14.04^{\prime}$ & 1220 & 1.93 & 0.265 & 8.5 & -21.1 & 5.6 & 85.9 \\
\hline 162 & $42^{\circ} 12.09^{\prime}$ & $144^{\circ} 16.91^{\prime}$ & 1345 & 1.40 & 0.195 & 8.4 & -21.1 & 6.4 & 81.5 \\
\hline 163 & $42^{\circ} 07.03^{\prime}$ & $144^{\circ} 20.02^{\prime}$ & 1381 & 1.58 & 0.220 & 8.4 & -20.7 & 5.7 & 87.5 \\
\hline 164 & $42^{\circ} 01.99^{\prime}$ & $144^{\circ} 24.01^{\prime}$ & 1558 & 1.29 & 0.179 & 8.4 & -21.1 & 5.8 & 69.4 \\
\hline 165 & $41^{\circ} 57.00^{\prime}$ & $144^{\circ} 28.00^{\prime}$ & 1754 & 1.26 & 0.175 & 8.4 & -21.2 & 5.4 & 58.1 \\
\hline
\end{tabular}




\begin{tabular}{|c|c|c|c|c|c|c|c|c|c|}
\hline $\operatorname{Stn}^{a}$ & Latitude & Longitude & $\begin{array}{c}\text { Water } \\
\text { depth } \\
(\mathrm{m}) \\
\end{array}$ & (weight \%) & (weight \%) & $\left(\mathrm{mol} \mathrm{mol}^{-1}\right)$ & (\%opDB $)$ & $\delta^{15} \mathrm{~N}$ & $\begin{array}{c}\text { Silt }+ \\
\text { Clay } \\
\text { (weight \%) }\end{array}$ \\
\hline 166 & $42^{\circ} 44.00^{\prime}$ & $143^{\circ} 53.99^{\prime}$ & 38 & 0.29 & 0.043 & 8.0 & -21.7 & 6.1 & 10.4 \\
\hline 167 & $42^{\circ} 39.95^{\prime}$ & $143^{\circ} 55.97^{\prime}$ & 78 & 0.65 & 0.088 & 8.7 & -21.2 & 6.3 & 26.9 \\
\hline 168 & $42^{\circ} 35.95^{\prime}$ & $143^{\circ} 57.90^{\prime}$ & 224 & 0.89 & 0.123 & 8.5 & -21.0 & 6.3 & 43.7 \\
\hline 169 & $42^{\circ} 32.02^{\prime}$ & $143^{\circ} 59.96^{\prime}$ & 454 & 0.90 & 0.121 & 8.7 & -20.9 & 6.0 & 58.4 \\
\hline 170 & $42^{\circ} 28.02^{\prime}$ & $144^{\circ} 02.04^{\prime}$ & 621 & 1.50 & 0.200 & 8.8 & -20.9 & 6.2 & 74.9 \\
\hline 171 & $42^{\circ} 23.95^{\prime}$ & $144^{\circ} 04.04^{\prime}$ & 766 & 1.71 & 0.252 & 7.9 & -20.9 & 6.1 & 59.4 \\
\hline 172 & $42^{\circ} 19.97^{\prime}$ & $144^{\circ} 05.97^{\prime}$ & 903 & 1.51 & 0.219 & 8.1 & -20.8 & 5.9 & 71.6 \\
\hline 174 & $42^{\circ} 12.03^{\prime}$ & $144^{\circ} 09.99^{\prime}$ & 1150 & 1.96 & 0.256 & 8.9 & -20.9 & 5.8 & 90.3 \\
\hline 175 & $42^{\circ} 07.99^{\prime}$ & $144^{\circ} 12.00^{\prime}$ & 1196 & 1.69 & 0.222 & 8.9 & -20.9 & 5.9 & 82.9 \\
\hline 176 & $42^{\circ} 02.98^{\prime}$ & $144^{\circ} 15.98^{\prime}$ & 1369 & 1.20 & 0.157 & 9.0 & -21.1 & 5.9 & 52.1 \\
\hline 177 & $41^{\circ} 57.98^{\prime}$ & $144^{\circ} 19.94^{\prime}$ & 1617 & 1.38 & 0.183 & 8.8 & -21.0 & 5.4 & 67.2 \\
\hline 178 & $42^{\circ} 39.86^{\prime}$ & $143^{\circ} 49.91^{\prime}$ & 43 & 0.45 & 0.054 & 9.6 & -22.2 & 6.2 & 15.4 \\
\hline 180 & $42^{\circ} 32.01^{\prime}$ & $143^{\circ} 54.00^{\prime}$ & 134 & 0.30 & 0.047 & 7.6 & -20.8 & 5.6 & 10.1 \\
\hline 181 & $42^{\circ} 27.99^{\prime}$ & $143^{\circ} 55.99^{\prime}$ & 382 & 0.60 & 0.083 & 8.3 & -20.9 & 6.4 & 31.1 \\
\hline 182 & $42^{\circ} 23.97^{\prime}$ & $143^{\circ} 58.01^{\prime}$ & 564 & 0.82 & 0.108 & 8.8 & -21.0 & 5.8 & 46.5 \\
\hline 183 & $42^{\circ} 19.78^{\prime}$ & $143^{\circ} 59.80^{\prime}$ & 770 & 0.94 & 0.135 & 8.1 & -20.9 & 5.8 & 55.0 \\
\hline 184 & $42^{\circ} 15.98^{\prime}$ & $144^{\circ} 02.00^{\prime}$ & 940 & 1.85 & 0.253 & 8.5 & -21.0 & 6.2 & 82.4 \\
\hline 186 & $42^{\circ} 08.00^{\prime}$ & $144^{\circ} 05.98^{\prime}$ & 1014 & 1.90 & 0.253 & 8.8 & -20.9 & 5.6 & 88.9 \\
\hline 188 & $41^{\circ} 58.95^{\prime}$ & $144^{\circ} 12.01^{\prime}$ & 1076 & 0.56 & 0.078 & 8.4 & -21.0 & 6.1 & 18.6 \\
\hline 189 & $42^{\circ} 36.02^{\prime}$ & $143^{\circ} 45.87^{\prime}$ & 47 & 1.37 & 0.138 & 11.6 & -23.0 & 4.5 & 33.3 \\
\hline 190 & $42^{\circ} 32.02^{\prime}$ & $143^{\circ} 47.98^{\prime}$ & 85 & 0.55 & 0.073 & 8.7 & -21.1 & 5.9 & 18.9 \\
\hline 191 & $42^{\circ} 27.98^{\prime}$ & $143^{\circ} 50.03^{\prime}$ & 138 & 0.33 & 0.051 & 7.6 & -20.6 & 5.9 & 12.1 \\
\hline 192 & $42^{\circ} 23.97^{\prime}$ & $143^{\circ} 52.01^{\prime}$ & 386 & 0.67 & 0.091 & 8.7 & -20.9 & 6.5 & 45.9 \\
\hline 193 & $42^{\circ} 19.99^{\prime}$ & $143^{\circ} 54.02^{\prime}$ & 611 & 1.18 & 0.164 & 8.4 & -20.9 & 6.2 & 59.9 \\
\hline 194 & $42^{\circ} 15.91^{\prime}$ & $143^{\circ} 55.98^{\prime}$ & 841 & 1.40 & 0.200 & 8.1 & -20.8 & 6.1 & 66.7 \\
\hline 195 & $42^{\circ} 11.80^{\prime}$ & $143^{\circ} 57.12^{\prime}$ & 933 & 1.63 & 0.218 & 8.7 & -21.0 & 5.8 & 86.8 \\
\hline 201 & $42^{\circ} 31.95^{\prime}$ & $143^{\circ} 42.07^{\prime}$ & 52 & 1.26 & 0.123 & 12.0 & -24.2 & 4.9 & 39.9 \\
\hline 202 & $42^{\circ} 27.98^{\prime}$ & $143^{\circ} 44.00^{\prime}$ & 90 & 0.31 & 0.044 & 8.1 & -20.9 & 5.9 & 17.1 \\
\hline 203 & $42^{\circ} 23.97^{\prime}$ & $143^{\circ} 46.03^{\prime}$ & 148 & 0.37 & 0.056 & 7.8 & -20.9 & 5.7 & 13.5 \\
\hline 204 & $42^{\circ} 19.90^{\prime}$ & $143^{\circ} 48.01^{\prime}$ & 434 & 1.16 & 0.158 & 8.6 & -20.9 & 6.0 & 66.5 \\
\hline 205 & $42^{\circ} 15.98^{\prime}$ & $143^{\circ} 49.99^{\prime}$ & 687 & 1.28 & 0.184 & 8.1 & -21.1 & 6.2 & 69.2 \\
\hline 210 & $42^{\circ} 27.96^{\prime}$ & $143^{\circ} 37.99^{\prime}$ & 55 & 1.12 & 0.109 & 12.0 & -23.4 & 5.1 & 23.6 \\
\hline 211 & $42^{\circ} 24.02^{\prime}$ & $143^{\circ} 40.01^{\prime}$ & 99 & 0.54 & 0.072 & 8.6 & -21.3 & 5.7 & 23.4 \\
\hline 212 & $42^{\circ} 20.03^{\prime}$ & $143^{\circ} 42.01^{\prime}$ & 146 & 0.44 & 0.063 & 8.2 & -21.2 & 5.6 & 17.3 \\
\hline 216 & $42^{\circ} 03.96^{\prime}$ & $143^{\circ} 50.05^{\prime}$ & 829 & 1.72 & 0.227 & 8.8 & -20.9 & 6.0 & 81.2 \\
\hline 219 & $42^{\circ} 24.02^{\prime}$ & $143^{\circ} 33.99^{\prime}$ & 54 & 0.70 & 0.081 & 10.1 & -22.6 & 5.6 & 22.2 \\
\hline 220 & $42^{\circ} 20.02^{\prime}$ & $143^{\circ} 35.95^{\prime}$ & 94 & 0.74 & 0.097 & 8.9 & -21.5 & 5.9 & 25.0 \\
\hline 221 & $42^{\circ} 16.01^{\prime}$ & $143^{\circ} 38.00^{\prime}$ & 135 & 0.61 & 0.083 & 8.6 & -21.2 & 5.7 & 23.5 \\
\hline 227 & $42^{\circ} 20.03^{\prime}$ & $143^{\circ} 29.97^{\prime}$ & 43 & 0.42 & 0.056 & 8.9 & -22.4 & 6.0 & 22.5 \\
\hline 228 & $42^{\circ} 15.97^{\prime}$ & $143^{\circ} 32.00^{\prime}$ & 83 & 1.01 & 0.124 & 9.5 & -22.1 & 5.6 & 37.5 \\
\hline 229 & $42^{\circ} 11.96^{\prime}$ & $143^{\circ} 33.98^{\prime}$ & 119 & 0.65 & 0.086 & 8.8 & -21.3 & 6.0 & 27.7 \\
\hline 231 & $42^{\circ} 03.98^{\prime}$ & $143^{\circ} 37.96^{\prime}$ & 235 & 0.58 & 0.080 & 8.4 & -20.8 & 5.8 & 20.5 \\
\hline 235 & $42^{\circ} 12.01^{\prime}$ & $143^{\circ} 27.99^{\prime}$ & 61 & 0.63 & 0.074 & 9.9 & -22.8 & 6.0 & 32.2 \\
\hline 236 & $42^{\circ} 07.80^{\prime}$ & $143^{\circ} 30.50^{\prime}$ & 109 & 1.27 & 0.161 & 9.2 & -22.1 & 5.7 & 43.7 \\
\hline 244 & $42^{\circ} 07.94^{\prime}$ & $143^{\circ} 23.98^{\prime}$ & 34 & 0.28 & 0.038 & 8.6 & -22.0 & 4.7 & 8.4 \\
\hline
\end{tabular}

a: At Stn. T-21 to T-43 and at Stn. 101 to 244, the samples were collected during the cruises of T/S Ushio-maru and during the GH02 cruise of R/V Hakurei-maru No. 2, respectively.

$\mathrm{b}$ : The $\mathrm{C}$ and $\mathrm{N}$ contents in the sediments are on dry weight basis after making the correction of weight loss during the pretreatments.

c: Not measured. 
Table 2. $\mathrm{C}$ and $\mathrm{N}$ isotope ratios in suspended particles and sediments, and related parameters in the Tokachi River

\begin{tabular}{|c|c|c|c|c|c|c|c|c|c|c|c|c|c|}
\hline Stn. & Date & $\begin{array}{c}\text { Antecedent } \\
\text { rainfall within } \\
10 \text { days }^{a} \\
(\mathrm{~mm})\end{array}$ & $\begin{array}{l}\text { Temp. } \\
\left({ }^{\circ} \mathrm{C}\right) \\
\end{array}$ & $\left(\mu S \mathrm{~cm}^{-1}\right)$ & $\left(\mathrm{mg} \mathrm{l}^{-1}\right)$ & $\left(\mu g ~^{-1}\right)$ & POC & $(\mu \mathrm{M})$ & (weight \%) & (weight \%) & $\left(\mathrm{mol} \mathrm{mol}^{-1}\right)$ & (\%opDB $)$ & $\left(\%{ }^{A I R}\right)$ \\
\hline \multicolumn{14}{|c|}{ River water } \\
\hline \multirow[t]{7}{*}{ Moiwa } & April 24, 2003 & $25(18-38)$ & 7.3 & 100 & 230 & $-\mathrm{b}$ & 125 & 8.40 & $-\mathrm{b}$ & $-b$ & 14.9 & $-b$ & $-b$ \\
\hline & May 10, 2003 & $35(20-59)$ & 9.0 & 80 & 160 & $-b$ & 45.0 & 3.68 & $-b$ & $-b$ & 12.2 & -27.8 & 1.7 \\
\hline & June 17, 2003 & $12(2-22)$ & 16.0 & 100 & 11 & $-\mathrm{b}$ & 33.0 & 4.20 & $-b$ & $-{ }^{b}$ & 7.9 & -26.2 & 1.2 \\
\hline & July 3, 2003 & $14(7-23)$ & 16.0 & 150 & 12 & $-b$ & 43.0 & 4.89 & $-b$ & $-{ }^{b}$ & 8.8 & -28.8 & 0.4 \\
\hline & August 4, 2003 & $36(23-57)$ & 19.1 & 128 & 11 & 1.64 & 20.6 & 3.19 & $-b$ & $-b$ & 6.5 & -25.2 & 1.5 \\
\hline & Sept. 26, 2003 & $27(7-45)$ & 11.7 & 120 & 110 & 6.60 & 147 & 18.5 & $-b$ & $-b$ & 8.0 & -25.2 & 2.5 \\
\hline & Nov. 6, 2003 & $28(13-73)$ & 7.5 & 130 & 25 & 1.29 & 62.3 & 7.62 & $-{ }^{b}$ & $-b$ & 8.2 & -27.3 & 1.4 \\
\hline Kako-1 & August 4, 2003 & $27(7-45)$ & 17.4 & 130 & 76 & 2.24 & 23.1 & 3.50 & $-b$ & $-{ }^{b}$ & 6.6 & -27.7 & 3.6 \\
\hline Kako-2 & August 4, 2003 & $27(7-45)$ & 17.9 & 340 & 41 & 3.09 & 19.7 & 3.22 & $-b$ & $-b$ & 6.1 & -28.1 & 4.1 \\
\hline Kako-3 & August 4, 2003 & $27(7-45)$ & 18.2 & 520 & 60 & 2.34 & 26.4 & 3.77 & $-b$ & $-{ }^{b}$ & 7.0 & -28.5 & 3.5 \\
\hline \multicolumn{14}{|l|}{ Sediment } \\
\hline Kako-1 & August 4, 2003 & $27(7-45)$ & $-b$ & $-b$ & $-b$ & $-b$ & $-b$ & $-b$ & 2.99 & 0.244 & 14.3 & -26.6 & 2.7 \\
\hline Kako-2 & August 4, 2003 & $27(7-45)$ & $-b$ & $-b$ & $-b$ & $-b$ & $-b$ & $-b$ & 1.55 & 0.116 & 15.6 & -26.9 & 2.4 \\
\hline Kako-3 & August 4, 2003 & $27(7-45)$ & $-b$ & $-\mathrm{b}$ & $-b$ & $-b$ & $-b$ & $-\mathrm{b}$ & 2.50 & 0.152 & 19.3 & -27.1 & 1.9 \\
\hline
\end{tabular}

a: Mean and range (value in the parentheses) of rainfall measured at 21 stations in the catchment of the Tokachi River by

Japan Meteorological Agency (www.jma.go.jp/JMA_HP/jma/indexe.html).

b: No data. 
Table 3. Temperature, salinity, nitrate plus nitrite, chlorophyll a (Chl.a), and the concentrations and isotope ratios of suspended POC and PN in seawater at Stn. T-35 off Tokachi.

\begin{tabular}{|c|c|c|c|c|c|c|c|c|c|c|}
\hline Date & Depth & Temp. & Salinity & $\begin{array}{c}\mathrm{NO}_{3}^{-}{ }^{-} \\
\mathrm{NO}_{2}^{-} \\
(\mu \mathrm{M})\end{array}$ & $\left(\mu \mathrm{gl}^{-1}\right)$ & $(\mu \mathrm{M})$ & $(\mu \mathrm{M})$ & $\left(\mathrm{mol} \mathrm{mol}^{-1}\right)$ & $\begin{array}{l}\delta^{13} \mathrm{C}- \\
\mathrm{POC} \\
(\% \text { PDB })\end{array}$ & $\begin{array}{c}\delta^{15} \mathrm{~N}- \\
\mathrm{PN} \\
\left(\% \mathrm{o}_{\mathrm{AIR}}\right)\end{array}$ \\
\hline \multirow[t]{19}{*}{ May 11,2003} & 0 & 3.35 & 32.72 & 0.2 & 13.6 & 54.1 & 6.58 & 8.2 & -19.7 & 6.9 \\
\hline & 5 & 2.93 & 32.78 & 0.2 & 12.2 & 56.5 & 6.09 & 9.3 & -19.3 & 6.3 \\
\hline & 10 & 2.01 & 32.81 & 0.2 & 11.9 & 55.8 & 7.11 & 7.8 & -18.8 & 6.3 \\
\hline & 20 & 1.66 & 32.83 & 9.0 & 9.82 & 29.8 & 4.53 & 6.6 & -20.0 & 4.0 \\
\hline & 30 & 1.39 & 32.85 & 10.1 & 9.10 & $-{ }^{a}$ & $-{ }^{a}$ & $-^{a}$ & $-{ }^{a}$ & $-^{a}$ \\
\hline & 40 & 1.28 & 32.85 & 13.9 & 5.42 & 17.8 & 2.78 & 6.4 & -21.3 & 3.1 \\
\hline & 50 & 1.10 & 32.87 & 17.3 & 5.40 & 14.2 & 2.23 & 6.4 & -21.4 & 3.2 \\
\hline & 60 & 0.88 & 32.90 & 18.1 & $-{ }^{a}$ & $-{ }^{a}$ & $-{ }^{a}$ & $-{ }^{a}$ & $-{ }^{a}$ & $-^{a}$ \\
\hline & 70 & 0.64 & 32.92 & 20.6 & 3.28 & 9.3 & 1.48 & 6.3 & -21.4 & 3.5 \\
\hline & 80 & 0.39 & 33.00 & 22.4 & $-{ }^{a}$ & $-{ }^{a}$ & $-{ }^{a}$ & $-^{a}$ & $-{ }^{a}$ & $-^{a}$ \\
\hline & 100 & 0.50 & 33.08 & 23.7 & 1.10 & 6.3 & 0.77 & 8.1 & -23.9 & 3.6 \\
\hline & 125 & 0.62 & 33.13 & 25.6 & $-{ }^{a}$ & $-{ }^{a}$ & $-{ }^{a}$ & $-^{a}$ & $-{ }^{a}$ & $-^{a}$ \\
\hline & 150 & 0.69 & 33.17 & 26.3 & 0.55 & 3.1 & 0.35 & 8.9 & -24.5 & 2.9 \\
\hline & 175 & 0.80 & 33.22 & 27.6 & $-{ }^{a}$ & $-{ }^{a}$ & $-{ }^{a}$ & $-^{a}$ & $-{ }^{a}$ & $-^{a}$ \\
\hline & 200 & 1.02 & 33.27 & 28.9 & $-^{a}$ & 3.1 & 0.30 & 10.4 & -24.7 & 3.6 \\
\hline & 250 & 1.31 & 33.37 & 30.8 & $-{ }^{a}$ & $-{ }^{a}$ & $-{ }^{a}$ & $-^{a}$ & $-{ }^{a}$ & $-^{a}$ \\
\hline & 300 & 1.64 & 33.47 & 33.1 & $-{ }^{a}$ & $-^{a}$ & $-{ }^{a}$ & $-^{a}$ & $-{ }^{a}$ & $-{ }^{a}$ \\
\hline & 400 & 1.95 & 33.57 & 35.0 & $-{ }^{a}$ & 2.8 & 0.16 & 17.7 & -27.3 & 4.8 \\
\hline & 500 & 2.51 & 33.75 & 39.1 & $-{ }^{a}$ & 2.0 & 0.12 & 15.9 & -27.6 & 4.8 \\
\hline \multirow[t]{19}{*}{ August 3, 2003} & 0 & 15.57 & 32.86 & 0.1 & 0.43 & $-{ }^{a}$ & $-^{a}$ & $-^{a}$ & $-{ }^{a}$ & $-{ }^{a}$ \\
\hline & 5 & 15.51 & 33.04 & 0.0 & 0.39 & 7.9 & 1.03 & 7.7 & -25.2 & 6.2 \\
\hline & 10 & 15.02 & 33.18 & 0.1 & 0.42 & 19.0 & 1.91 & 9.9 & -26.1 & 6.3 \\
\hline & 20 & 7.57 & 32.85 & 0.7 & 1.59 & $-{ }^{a}$ & $-{ }^{a}$ & $-^{a}$ & $-{ }^{a}$ & $-^{a}$ \\
\hline & 30 & 4.94 & 32.97 & 9.8 & 1.07 & 8.0 & 1.04 & 7.7 & -26.3 & 3.8 \\
\hline & 40 & 3.58 & 32.99 & 17.2 & 0.24 & $-{ }^{a}$ & $-{ }^{a}$ & $-{ }^{a}$ & $--^{a}$ & $-^{a}$ \\
\hline & 50 & 2.66 & 33.05 & 18.9 & 0.12 & 2.9 & 0.33 & 8.9 & -27.1 & 4.0 \\
\hline & 60 & 2.19 & 33.09 & 21.1 & $-{ }^{a}$ & $-{ }^{a}$ & $-{ }^{a}$ & $-^{a}$ & $-{ }^{a}$ & $-^{a}$ \\
\hline & 70 & 1.98 & 33.11 & 22.1 & 0.05 & $-{ }^{a}$ & $-^{a}$ & $-{ }^{a}$ & $-{ }^{a}$ & $-{ }^{a}$ \\
\hline & 80 & 2.06 & 33.12 & 22.6 & $-{ }^{a}$ & $-{ }^{a}$ & $-{ }^{a}$ & $-^{a}$ & $-^{a}$ & $-{ }^{a}$ \\
\hline & 100 & 1.98 & 33.17 & 24.0 & 0.05 & 2.5 & 0.18 & 13.7 & -27.3 & 8.6 \\
\hline & 125 & 2.43 & 33.28 & 24.2 & 0.03 & $-{ }^{a}$ & $-{ }^{a}$ & $-^{a}$ & $--^{a}$ & $-^{a}$ \\
\hline & 150 & 2.27 & 33.31 & 24.6 & $-{ }^{a}$ & $-{ }^{a}$ & $-^{a}$ & $-{ }^{a}$ & $-{ }^{a}$ & $-{ }^{a}$ \\
\hline & 175 & 1.72 & 33.30 & 27.0 & $-{ }^{a}$ & $-{ }^{a}$ & $-{ }^{a}$ & $-^{a}$ & $-{ }^{a}$ & $-{ }^{a}$ \\
\hline & 200 & 1.71 & 33.33 & 28.7 & $-{ }^{a}$ & 2.2 & 0.17 & 12.7 & -27.1 & 7.6 \\
\hline & 250 & 2.03 & 33.47 & 34.3 & $-^{a}$ & $-{ }^{a}$ & $-{ }^{a}$ & $-^{a}$ & $-{ }^{a}$ & $-^{a}$ \\
\hline & 300 & 2.12 & 33.56 & 34.4 & $-{ }^{a}$ & $-{ }^{a}$ & $-{ }^{a}$ & $-{ }^{a}$ & $-{ }^{a}$ & $-{ }^{a}$ \\
\hline & 400 & 2.38 & 33.65 & 38.1 & $-{ }^{a}$ & $-{ }^{a}$ & $-{ }^{a}$ & $-^{a}$ & $-{ }^{a}$ & $-{ }^{a}$ \\
\hline & 500 & 2.94 & 33.86 & 42.0 & $-{ }^{a}$ & 4.0 & 0.16 & 24.6 & -28.4 & 6.7 \\
\hline
\end{tabular}


Table 3. (continued)

Date Depth Temp. Salinity $\mathrm{NO}_{3}{ }^{-}+$Chl.a $\mathrm{POC} \quad \mathrm{PN} \quad \mathrm{C} / \mathrm{N} \quad \delta^{13} \mathrm{C}-\delta^{15} \mathrm{~N}-$ $\mathrm{NO}_{2}^{-} \quad$ POC PN

\begin{tabular}{|c|c|c|c|c|c|c|c|c|c|c|}
\hline & $(\mathrm{m})$ & $\left({ }^{\circ} \mathrm{C}\right)$ & & $(\mu \mathrm{M})$ & $\left(\mu \mathrm{g} \mathrm{I}^{-1}\right)$ & $(\mu \mathrm{M})$ & $(\mu \mathrm{M})$ & $\left(\mathrm{mol} \mathrm{mol}{ }^{-1}\right)$ & (\%opDB $)$ & $\left(\% \mathrm{oAIR}_{\mathrm{A}}\right)$ \\
\hline \multirow[t]{19}{*}{ Nov. 1, 2003} & 0 & 10.54 & 33.31 & 3.0 & 3.65 & 17.9 & 3.18 & 5.6 & -19.4 & 4.5 \\
\hline & 5 & 10.54 & 33.31 & 3.2 & 3.47 & 16.8 & 2.69 & 6.2 & -19.9 & 4.0 \\
\hline & 10 & 10.24 & 33.31 & 4.0 & 2.63 & 17.0 & 2.32 & 7.3 & -21.3 & 3.7 \\
\hline & 20 & 10.13 & 33.33 & 3.5 & 3.07 & 11.5 & 1.80 & 6.4 & -19.7 & 3.4 \\
\hline & 30 & 9.97 & 33.33 & 4.6 & 2.23 & $-{ }^{a}$ & $-{ }^{a}$ & $-{ }^{a}$ & $--^{a}$ & $--^{a}$ \\
\hline & 40 & 9.52 & 33.32 & 6.9 & 1.99 & $-{ }^{a}$ & $-{ }^{a}$ & $-^{a}$ & $-{ }^{a}$ & $-{ }^{a}$ \\
\hline & 50 & 7.82 & 33.19 & 12.0 & 1.28 & 6.0 & 0.91 & 6.6 & -23.4 & 4.2 \\
\hline & 60 & 7.55 & 33.28 & 17.0 & $-{ }^{a}$ & $-{ }^{a}$ & $-{ }^{a}$ & $-{ }^{a}$ & $-{ }^{a}$ & $-{ }^{a}$ \\
\hline & 70 & 7.33 & 33.29 & 17.2 & $-{ }^{a}$ & $-{ }^{a}$ & $-{ }^{a}$ & $-^{a}$ & $-{ }^{a}$ & $-{ }^{a}$ \\
\hline & 80 & 6.73 & 33.24 & 18.2 & 0.30 & $-{ }^{a}$ & $-{ }^{a}$ & $-^{a}$ & $-{ }^{a}$ & $-{ }^{a}$ \\
\hline & 100 & 5.91 & 33.23 & 22.2 & 0.20 & 2.2 & 0.36 & 6.1 & -24.5 & 6.6 \\
\hline & 125 & 4.06 & 33.20 & $-{ }^{a}$ & 0.25 & $-{ }^{a}$ & $--^{a}$ & $-^{a}$ & $--^{a}$ & $--^{a}$ \\
\hline & 150 & 3.26 & 33.21 & $-{ }^{a}$ & $-{ }^{a}$ & $-{ }^{a}$ & $-^{a}$ & $-^{a}$ & $-{ }^{a}$ & $-{ }^{a}$ \\
\hline & 175 & 2.46 & 33.23 & $-{ }^{a}$ & $-{ }^{a}$ & $-{ }^{a}$ & $-{ }^{a}$ & $-^{a}$ & $-{ }^{a}$ & $-{ }^{a}$ \\
\hline & 200 & 2.10 & 33.27 & $-{ }^{a}$ & $-{ }^{a}$ & 1.3 & 0.17 & 7.2 & -26.3 & 7.6 \\
\hline & 250 & 1.92 & 33.38 & $-{ }^{a}$ & $-{ }^{a}$ & $-{ }^{a}$ & $-{ }^{a}$ & $-{ }^{a}$ & $-{ }^{a}$ & $--^{a}$ \\
\hline & 300 & 1.99 & 33.47 & $-^{a}$ & $-{ }^{a}$ & $-{ }^{a}$ & $--^{a}$ & $-^{a}$ & $--^{a}$ & $-{ }^{a}$ \\
\hline & 400 & 2.36 & 33.67 & $-^{a}$ & $-{ }^{a}$ & 2.4 & 0.26 & 9.0 & -25.6 & 7.4 \\
\hline & 500 & 2.54 & 33.74 & $-{ }^{a}$ & $-{ }^{a}$ & 2.2 & 0.25 & 8.5 & -25.0 & 7.2 \\
\hline
\end{tabular}

a: Not measured. 


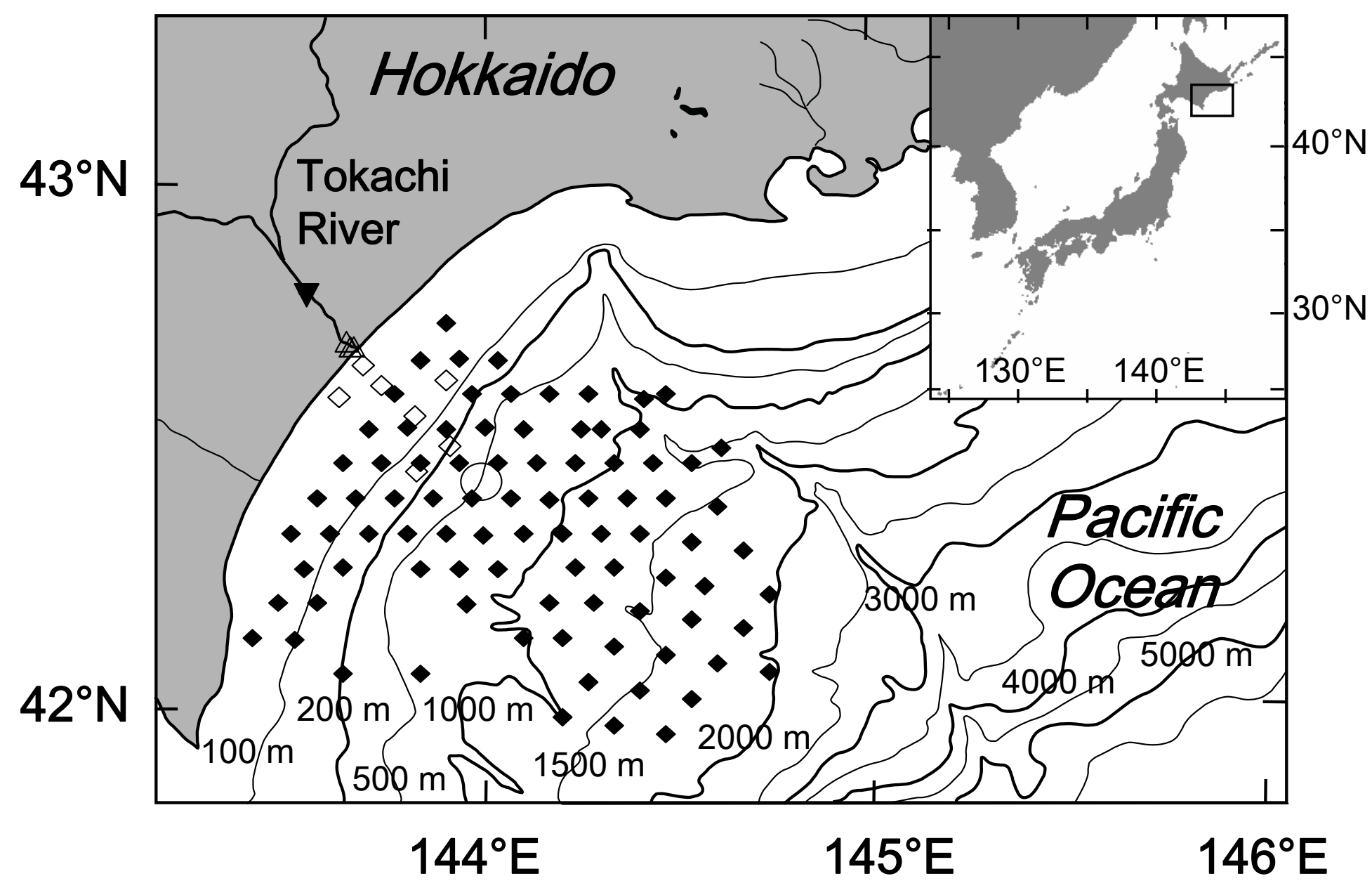

Usui et al., Fig. 1 

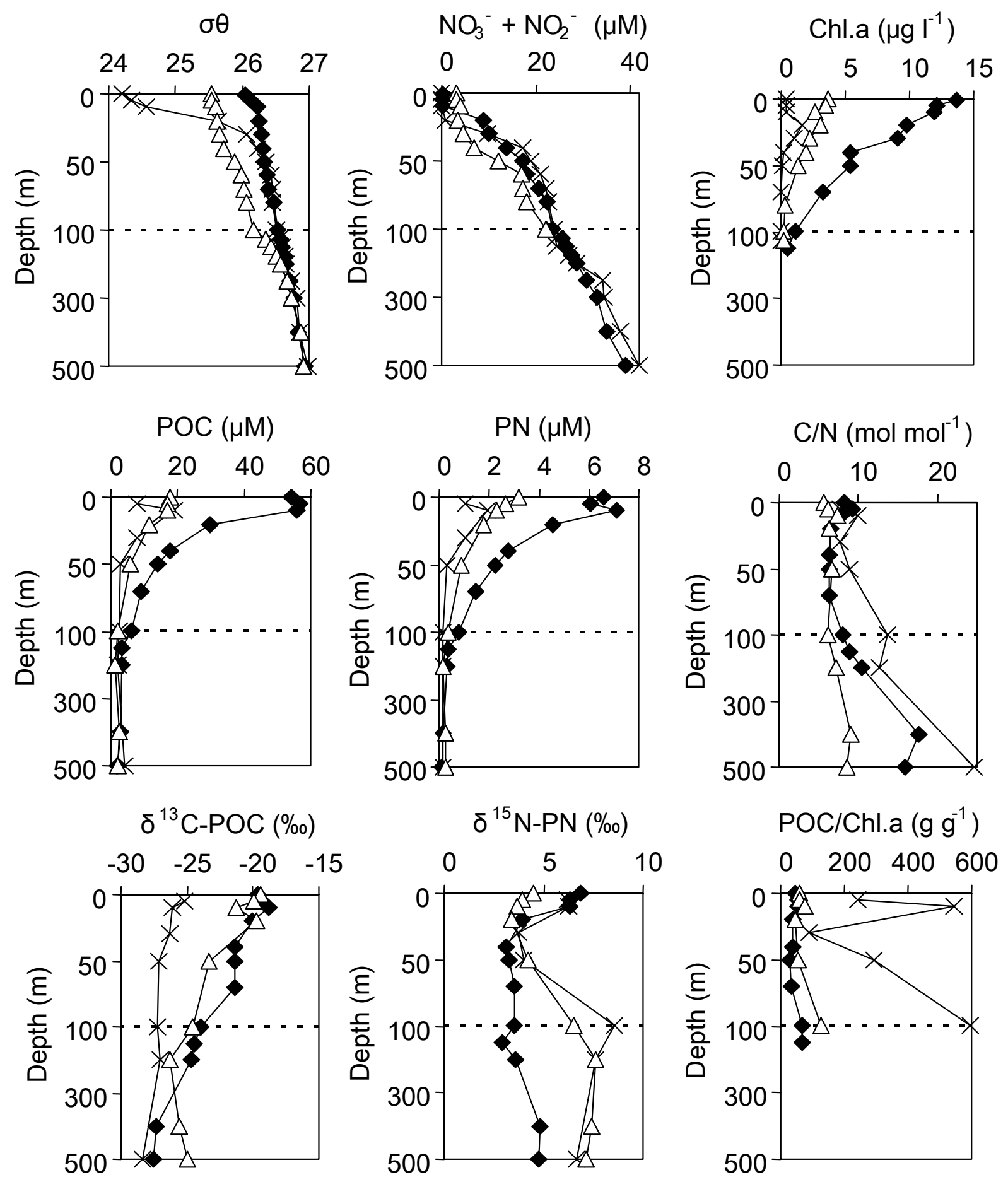

Usui et al., Fig. 2 


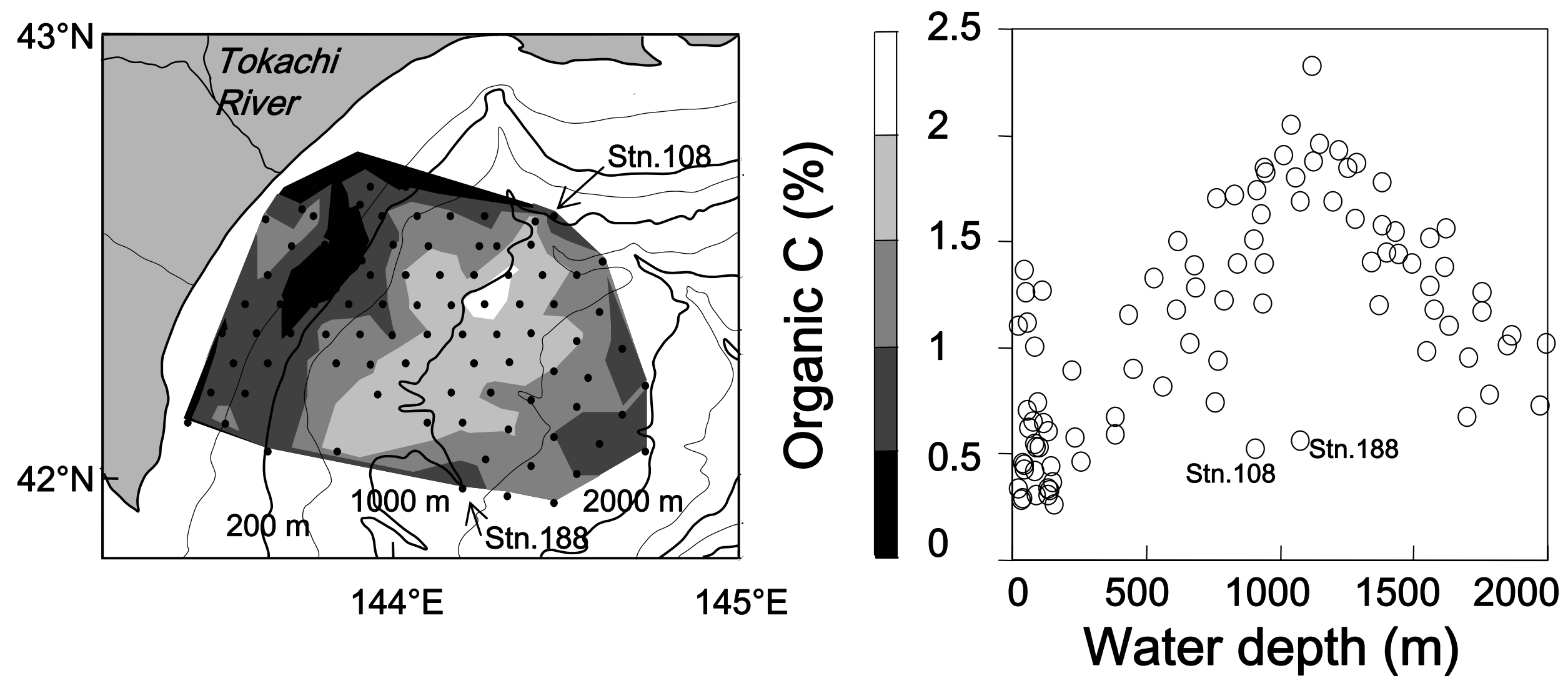

Usui et al., Fig. 3 


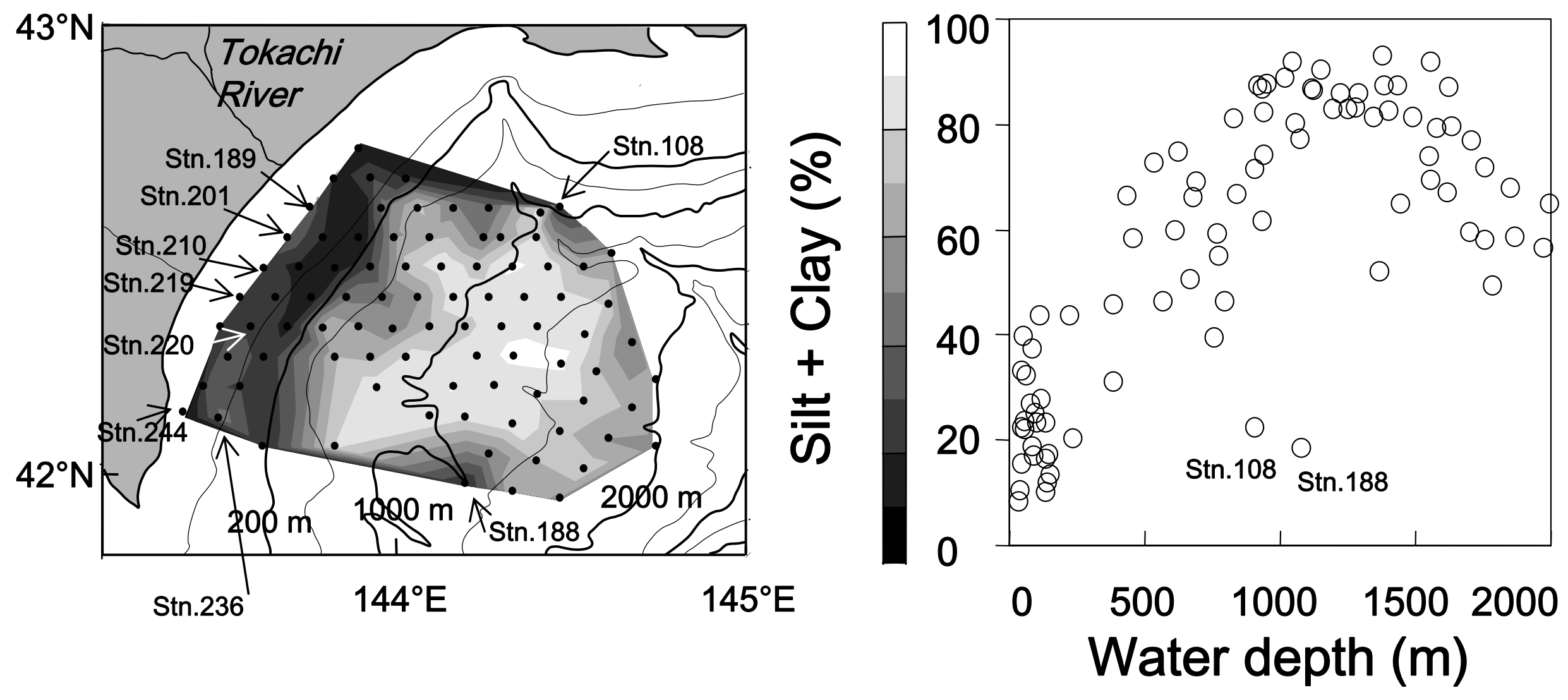

Usui et al., Fig. 4 


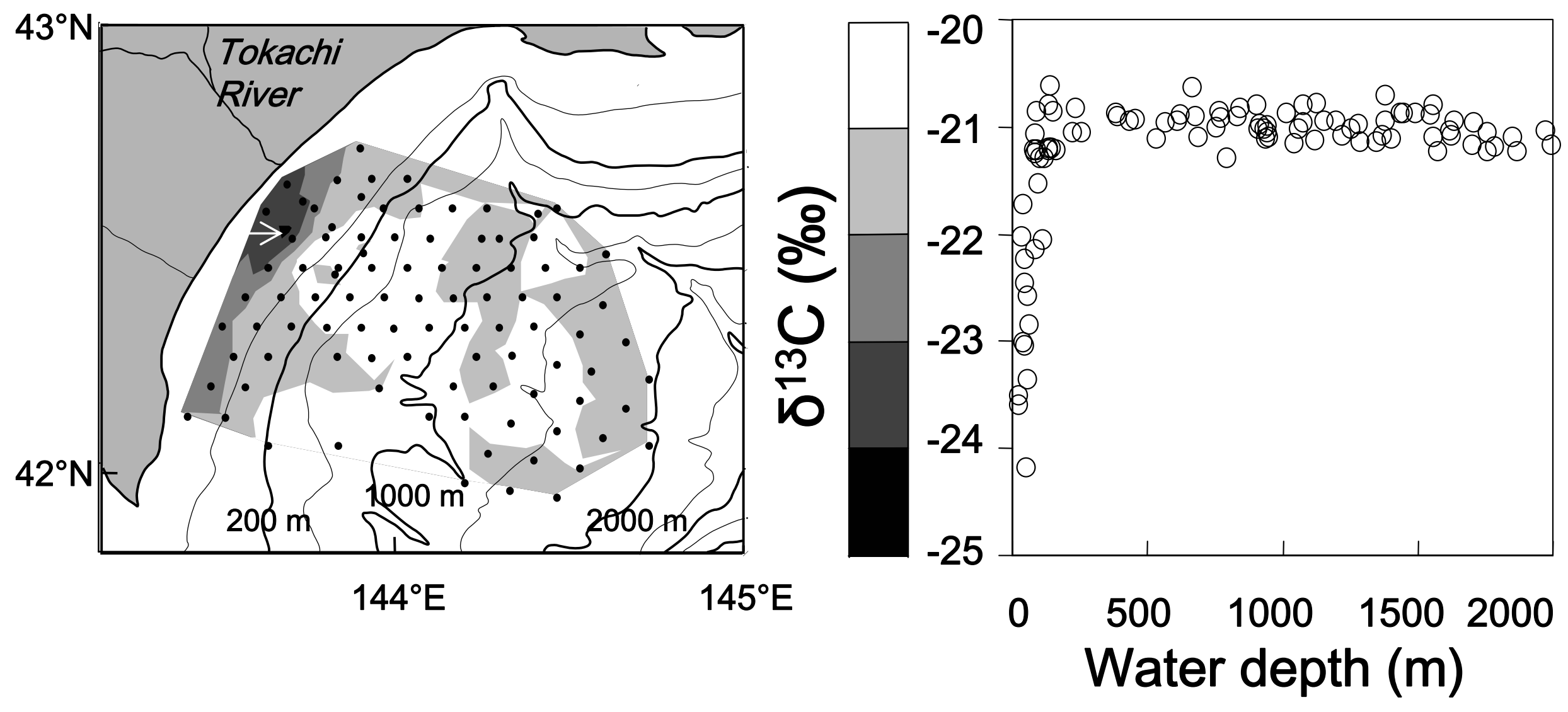

Usui et al., Fig. 5 


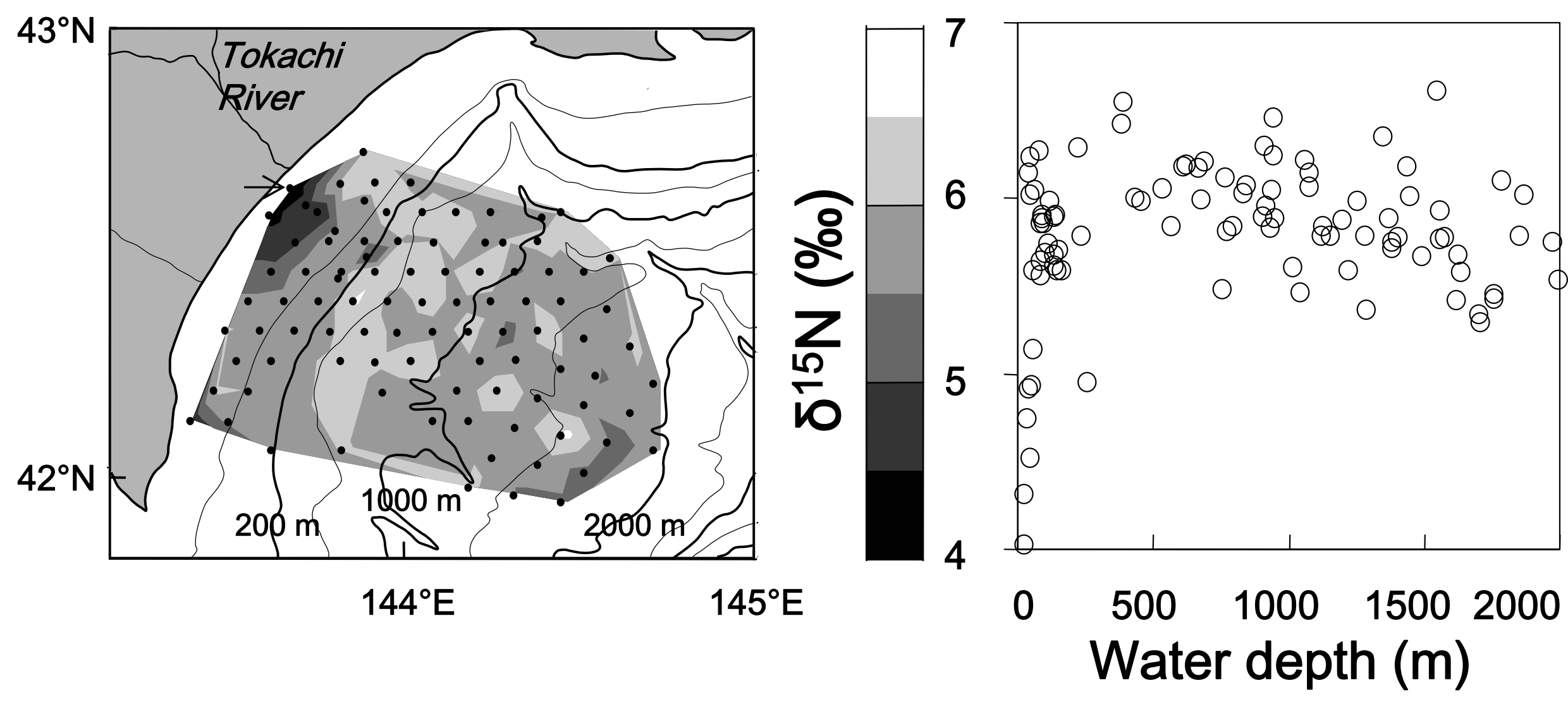

Usui et al., Fig. 6 


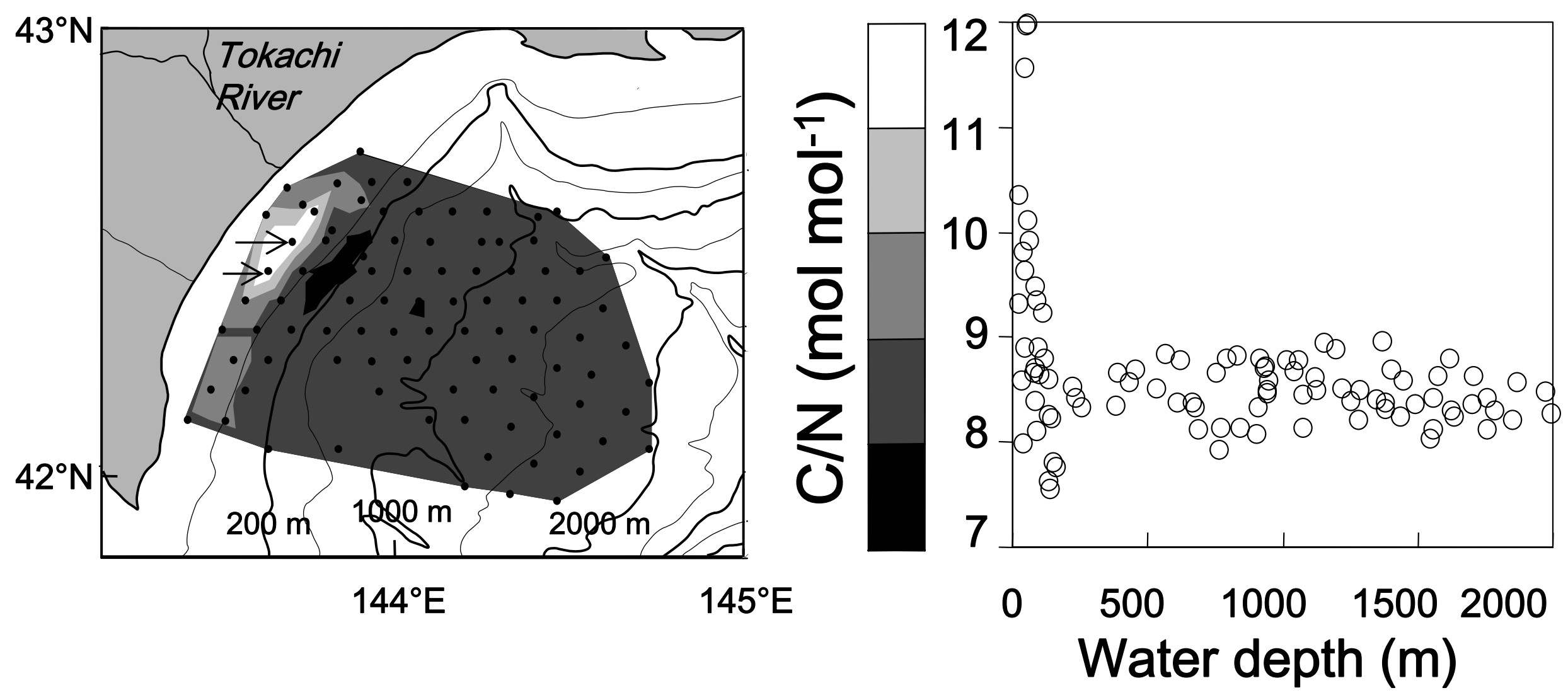

Usui et al., Fig. 7 

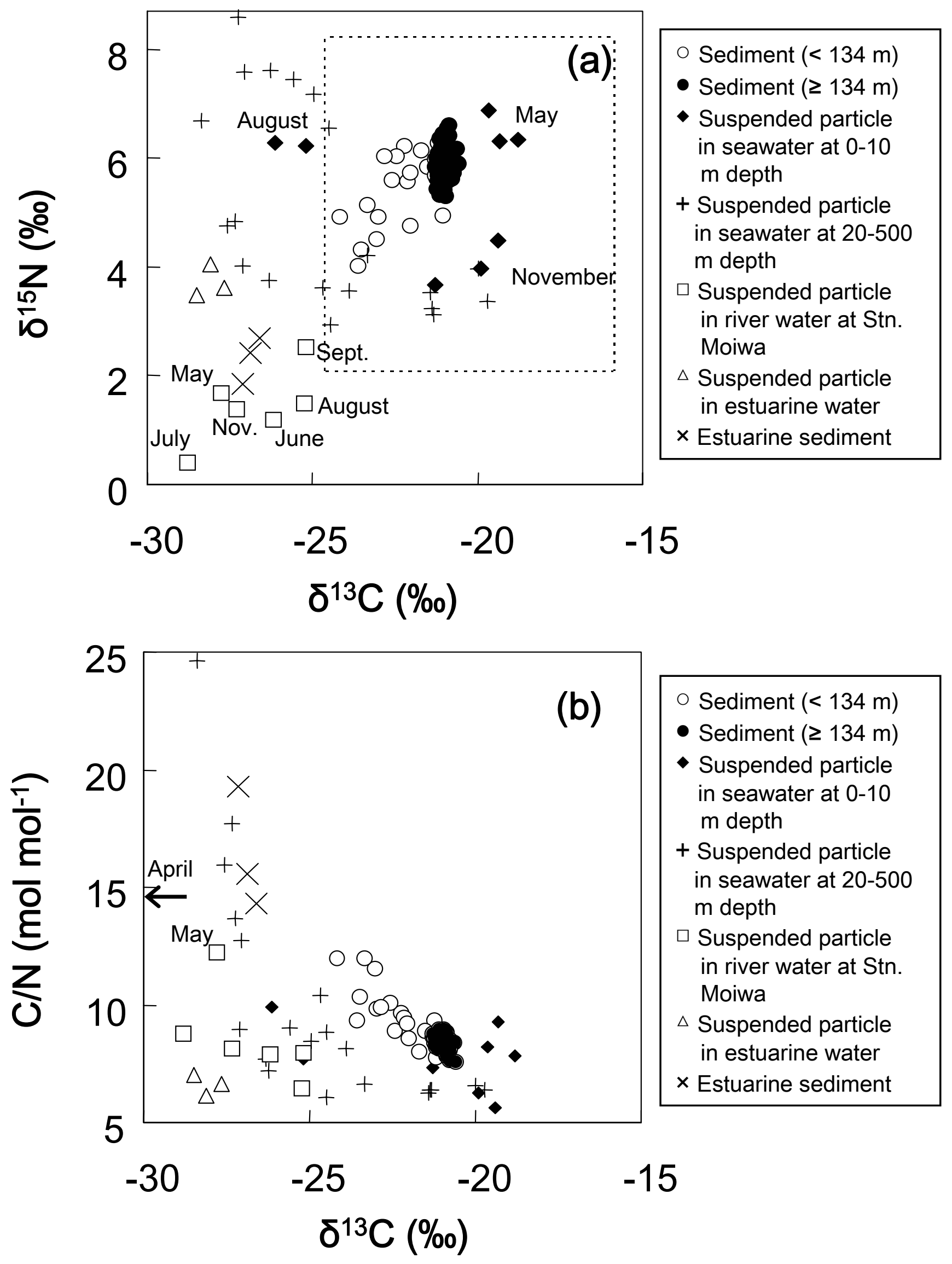

Usui et al., Fig. 8 


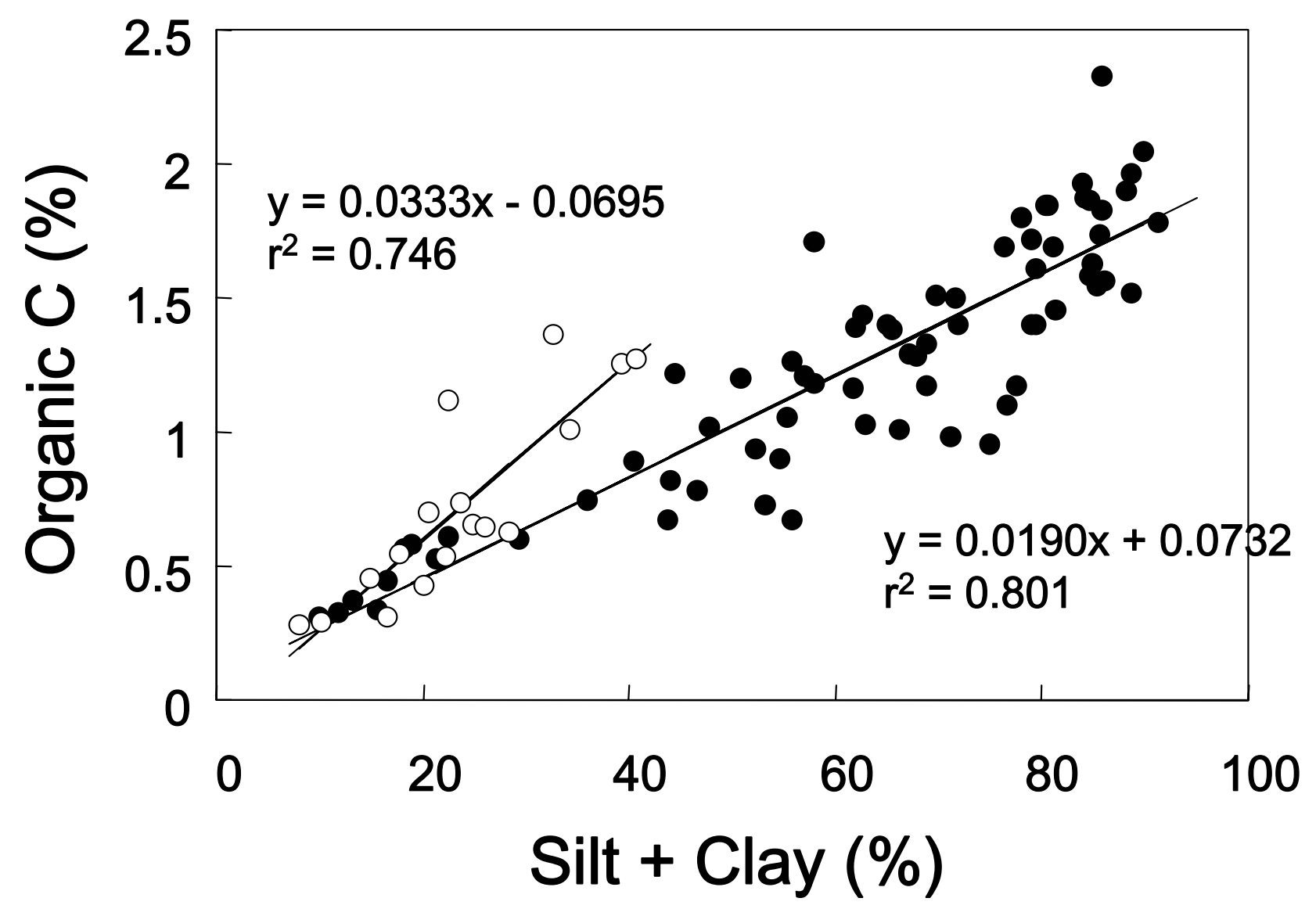

Usui et al., Fig. 9 

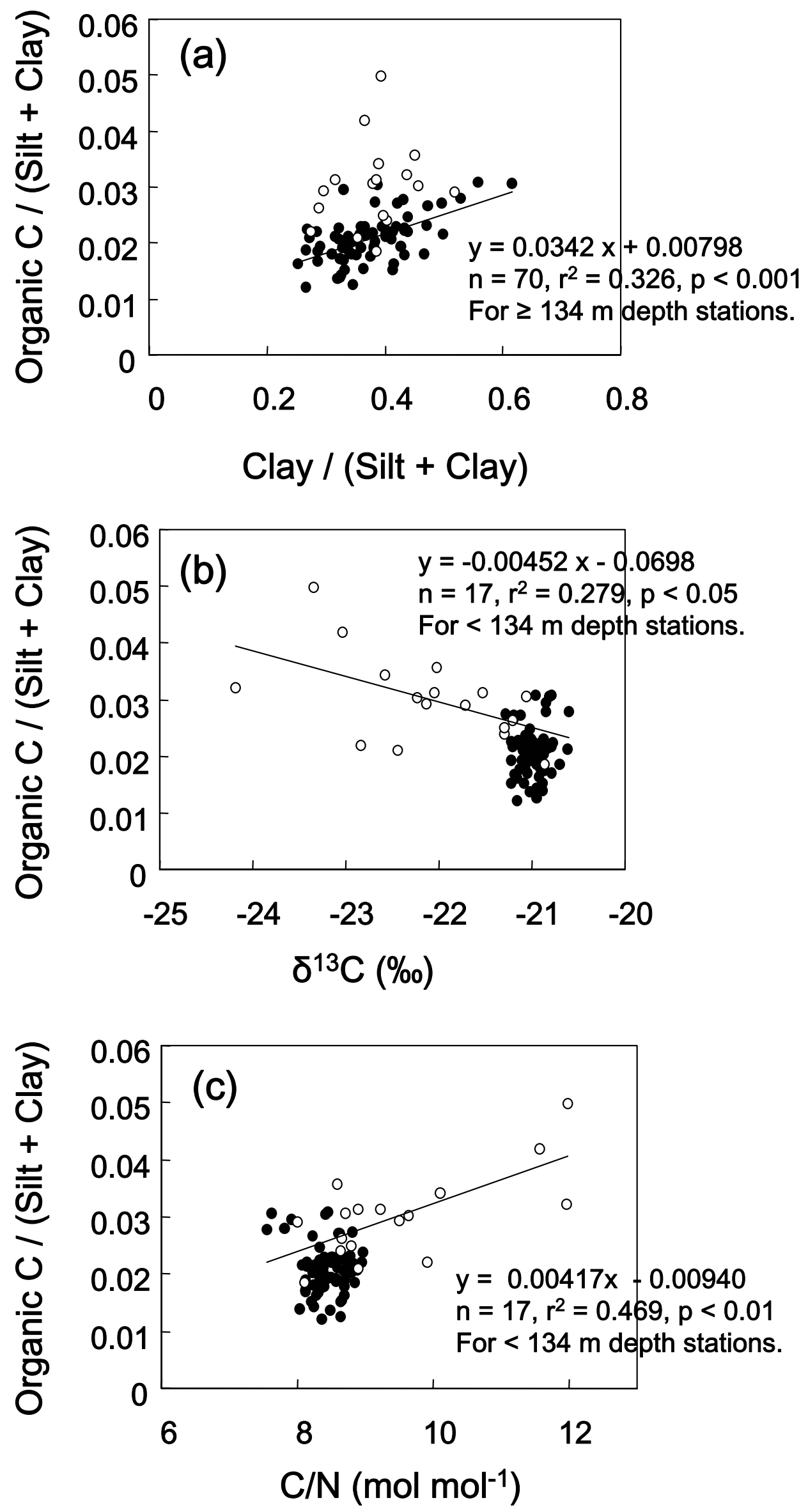

Usui et al., Fig. 10 